\title{
On the Origins of the Ergative Marker wã in the Viceitic Languages of the Chibchan Family
}

\author{
Sara Pacchiarotti
}

Bribri and Cabécar are Chibchan languages spoken in Costa Rica in contiguous territories. ${ }^{1}$ Both languages display two distinct ergative markers, diachronically unrelated in any obvious way. The canonical, standard ergative marker is tö in Bribri (1) and të in Cabécar (2). A further ergative marker wã seems to be construction-determined and is more restricted in terms of usage. It is found, among others, in the perfect construction, cf. (3) and (4).

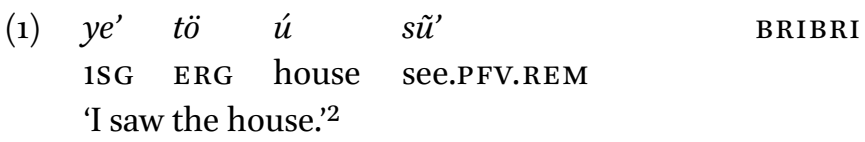

1 I am grateful to Alí García Segura, native Bribri speaker, and to Severiano Fernández Torres, native Cabécar speaker, for their invaluable help and patience, without whom this article would not have been possible. I am much indebted to Spike Gildea who guided my reasoning in the right direction during the entire writing process. I am grateful to Doris Payne, Miguel Angel Quesada Pacheco, Eric Campbell, Scott DeLancey and two anonymous reviewers for insightful comments, critiques and discussion on earlier drafts of this article. All errors and shortcomings are my own.

2 The marking of nasality follows the conventions established in Constenla et al. (1998), not those of Jara Murillo \& García Segura (2013). However, unlike Constenla et al. (1998) I use the symbol $<\tilde{a}>$, not $<\underline{a}>$, to mark nasality. The data in this article comes from the dialectal variety of Bribri spoken in Coroma. In my description, unlike others, falling tone is indicated as $<\hat{\mathbf{a}}>$, whereas high tone is indicated as $<$ á $>$. Low tone is not marked in the orthography. It should be noted, however, that the tonal system of Bribri is poorly described and more work is needed in order to fully understand it. The examples report tonal transcriptions found in the original text wherever applicable, adapted to the tonal conventions set out above. In addition, elicited examples are transcribed differently from examples found in other sources. In elicited examples, I transcribe the reduced set of short personal pronouns ${ }_{\mathrm{i}} \mathrm{SG}[\mathrm{f}] /[\mathrm{p}]$, $\left.{ }_{2} \mathrm{SG}[\mathrm{b}] /[\mathrm{m}],{ }_{3} \mathrm{SG}[\mathrm{i}] /[\mathrm{j}],{ }_{1} \mathrm{PL}[\mathrm{s}]\right)$ as prefixes, and the negation morpheme ké as a pro-clitic. I refer the interested reader to Chevrier (2017) for phonological arguments in favor of this classification. The abbreviation (EL) means data is from elicitation. Abbreviations for Bribri and other languages considered in this article are as follows: $1=$ first person, $2=$ second person, $3=$ third person, $\mathrm{ASP}=$ aspectual marker, $\mathrm{COMPL}=$ complementizer, $\mathrm{CPL}=$ completive aspect; 
(2) yís të jũ síu-l

CABÉCAR

1SG ERG house see-PFV.REM

'I saw the house.'3 (EL)

$\begin{array}{llll}\text { (3) } y e^{\prime} & w \tilde{a} & u & \text { sú-ule } \\ \text { 1SG } & \text { ERG } & \text { house } & \text { see-PTCP }\end{array}$

BRIBRI

'I have seen the house.' (EL)

(4) yís wã jũ sú́-le

CABÉCAR

1SG ERG house see-PTCP

'I had seen the house.' (EL)

In previous literature, it has been argued that the Agent NP followed by wã in Bribri has a by-phrase (i.e. oblique) status (Constenla et al. 1998: 112). In contrast, I demonstrate that the NP marked by the postposition $w \tilde{a}$ has the same subject properties as an NP marked by the canonical ergative postposition $t \ddot{0} .^{4}$ For instance, the latter controls co-reference of a 3 rd person anaphoric pronoun in a following coordinate clause (5).

$\mathrm{DST}=$ distal, $\mathrm{ERG}=$ ergative postposition, $\mathrm{EXCL}=$ exclusive, $\mathrm{GEN}=$ genitive, $\mathrm{H}=$ human, $\mathrm{HAB}=$ habitual, IDP = ideophone, INF = infinitive, INT = intensifier, IPFV= imperfective, IPFV II = additional imperfective suffix expressing habitual or near future meanings, $\mathrm{MVC}=$ middle voice cluster, $\mathrm{NEG}=$ negation, $\mathrm{NF}=$ non-focusable (in reference to pronouns), $\mathrm{OBL}=$ oblique (i.e. pronoun from the oblique set), $\mathrm{PFV}=$ perfective, $\mathrm{PL}=$ plural, $\mathrm{POS}=$ positional (existential verb which specifies the position in which its argument is found), POSS= possessive suffix, $\mathrm{PRX}=$ proximal, $\mathrm{PSSR}=$ possessor, $\mathrm{PST}=$ past, $\mathrm{PTCP}=$ participle, $\mathrm{REC}=$ recent, $\mathrm{REM}=$ remote, $\mathrm{SG}=$ singular.

3 High tone is indicated as <á > and low tone is not marked in the orthography.

4 Bribri is morphologically (i.e. "surface") ergative but syntactically accusative. By 'Subject' here I mean the syntactic grouping of $\mathrm{S}$ and $\mathrm{A}$, as is most typically found in nominativeaccusative languages. The emic category of Subject is shown to exist in Bribri by properties such as control of co-reference and Subject to Object raising (see Dickeman-Datz 1984).

5 This example and others similar to this one in terms of semantic/ pragmatic oddity have been elicited following the work of Hoff (1995: 362$)$. In examples 5 and 6, the pronoun $i e^{\prime}$ can refer to a male or female referent. If the person who becomes angry is 'Trini', there are two possibilities: either the NP 'Trini' needs to be repeated in the coordinate clause, or the demonstrative pronoun $e$ 'that' needs to be used. 
The NP marked by wã shows the same ability (6).
Alíwã Trini wöalátsë-ule ẽnã ie'
ulú-n-ẽ
BRIBRI

A. ERG T. kiss-PTCP and 3SG.PRX.H become.angry-MVC-PFV

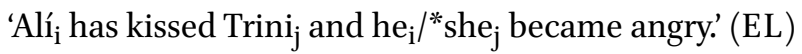

The same behavior is observed in Cabécar, as shown in (7) and (8).

(7) Trini të Severiano wöalats-á jẽnã jie' ulú-nã CABÉCAR T. ERG S. kiss-PFV.REC and 3SG become.angry-MVC.PFV.REC 'Trini $\mathrm{i}_{\mathrm{i}}$ kissed Severiano $_{\mathrm{j}}$ (and) then she $\mathrm{e}_{\mathrm{i}}{ }^{*} \mathrm{he}_{\mathrm{j}}$ became angry.' (EL)

(8) Trini wã Severiano wöalatsë-le jẽnã jie'

Trini ERG S. kiss-PTCP and 3SG

ulú-nã-wã

CABÉCAR

become.angry-MVC.PFV.REC-ASP

'Trini ${ }_{\mathrm{i}}$ had kissed Severiano $\mathrm{j}_{\mathrm{j}}$ and she $_{\mathrm{i}} /{ }^{*} \mathrm{he}_{\mathrm{j}}(\mathrm{had})$ become angry'. (EL)

In the typological literature, a system with two non-allomorphic and diachronically unrelated ergative markers is called "differential ergative marking" (McGregor 2009) and is reported to be quite uncommon (see Arkadiev 2017 for a survey). The ergative marker wã also constitutes, in these two Chibchan languages, an instance of case syncretism with the possessor in possessive predications. It is important to stress that the term possessor should not be conflated with genitive case marking. In this article, the term genitive is restricted to case marking in attributive possession (i.e. on a noun within a possessive NP), while the term possessor is restricted to the subject of a possessive predication (i.e. a full clause which expresses a possessive relation). In Bribri and Cabécar, the case syncretism is syntactic rather than semantic; the subject possessor bears the morpheme wã , cf. (9) and (10), whereas the semantic possessor in attributive possession is unmarked in both languages, cf. (11) and (12).

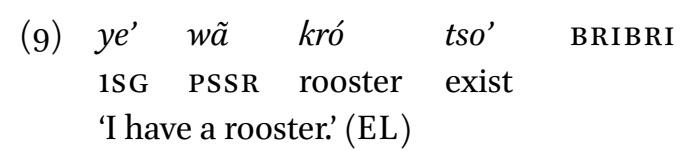

$\begin{array}{lllll}\text { (10) yís } & w a ̃ & \text { jóshkoro } & \text { tsố } & \text { CABÉCAR } \\ \text { 1SG } & \text { PSSR } & \text { rooster } & \text { exist }\end{array}$

'I have a rooster.' (EL) 
(11) $s a^{\prime} \quad \dot{u}$ BRIBRI

1PL.EXCL house

'Our house' (EL)

(12) sá jũ CABÉCAR

1PL.EXCL house

'Our house' (EL)

From a diachronic perspective, one might wonder how the synchronic syncretism between a possessor and an ergative marker came to be and what could be the ultimate source of the ergative marker wã. In other languages, other case markers are among the most widely attested sources of ergative case markers, followed by demonstratives and pronouns (McGregor 2009: 499). In particular, possessor markers are the third most widely attested source for ergative markers (Palancar 2002: 41). Languages that display this phenomenon are found in the Eskimo-Aleutian, Tibeto-Burman, Mayan and, peripherally, Caucasian language families.

In the light of such typological considerations, I will demonstrate that the diachronic source of the ergative marker $w \tilde{a}$ in the perfect construction is the possessor marker found in possessive predications. Furthermore, based on a syntactic comparison of possessive predications within the Isthmic branch of the Chibchan family, I will argue that the ergative marker wã can be traced back to Proto-Chibchan as a possessor marker, whereas the more canonical ergative marker tö reconstructs as such to Proto-Chibchan *tV (Constenla 2008: 131).

The article is organized as follows: $\$ 2$ offers a genealogical characterization of the Chibchan family and a concise typological sketch of Bribri and Cabécar. $\$ 3$ is divided into several sub-sections and deals with: (i) the internal reconstruction of the evolution of the possessor marker wã into an ergative marker in the perfect construction in Bribri, as well as arguments for directionality (\$3.1); (ii) the existence of a parallel reanalysis in Cabécar $(\$ 3.2)$; and (iii) the identification of cognate constructions for the perfect and possessive predication in Bribri (\$3.3). §4 traces the presence of the possessor marker in alienable possessive predications in other Chibchan languages of the Isthmic branch. This section shows that the source of the possessor marker $w \tilde{a}$ (later reanalyzed as an ergative marker in some of the languages) can be traced back to a Proto-Chibchan word meaning 'something' or 'belonging'. The comparative method will be used to show evidence of cognacy between the proto-form and the reflexes in different languages (details in Appendices A and B). §5 concludes the article. 


\section{Genealogical Classification of the Chibchan Languages}

The Chibchan family was established by means of historical comparative reconstruction by Uhle (1890) and was later confirmed by Constenla (1981, 1988, 1989, 2012) and Holt (1986). Further work applied lexicostatistics to this family (Constenla 1985). Compared to other language families, this family is quite heterogeneous and only a nucleus of basic vocabulary can be reconstructed (Pache 2016). Constenla (1991) places the Chibchan family in what he calls the geographically "Intermediate Area", which is divided as follows: (a) part of the Venezuelan-Antillean Area; (b) the Ecuadorian-Colombian sub-area of the Andes Area; and (c) the Colombian-Central American Area, which is in turn divided into (c1) the Central Sub-area and (c2) the North Sub-area and East Sub-area.

The Chibchan family is part of the Central Sub-area (c1). Figure 6.1 offers a map with the geographical location of modern Chibchan languages comprised in the Colombian-Central American Area (c). The symbol $\dagger$ means that a given language is now extinct.

According to Constenla (1991), in the Colombian-Central American Area (c), there are, among others, the following general linguistic features: (i) exclusively sov order as the basic order of the transitive clause (as opposed to

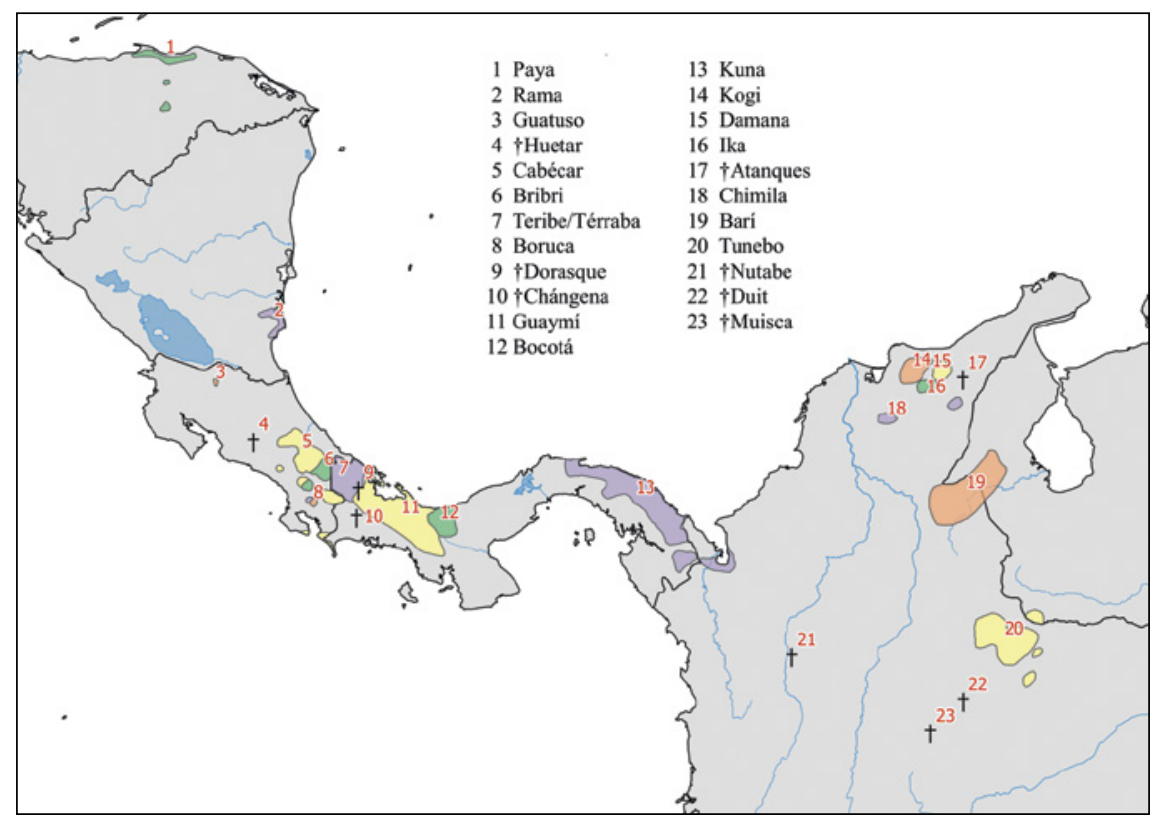

FIGURE 6.1 Approximate distribution of Chibchan languages (taken from Pache 2018: 2) 
the Mesoamerican area and the Venezuelan Antillean area); (ii) exclusive use of postpositions; (iii) almost complete absence of gender oppositions in pronouns; (iv) scarcity of inflections; and (iv) absence of accusative case marking. The languages of the Central Sub-area ( $\mathrm{cr}$ ), show, among others, the following features: (i) ergative or active-stative case systems and (ii) absence of inflection for person marking. The marking of genitive case, or possession, by means of suffixation or postpositions is present in a third of the languages. In some, this kind of marking is restricted to some possession relations, usually alienable possession or those in which the possessor is a person.

So far, the reconstruction of Proto-Chibchan has been concerned mainly with phonology and only marginally with nominal and verbal morphology. Constenla (2008: 129 ff.) argues that it is very likely that Proto-Chibchan did not have nominal inflection or, if it did, it was extremely reduced. As for verbal morphology, the following morphemes, among others, have been reconstructed: (i) $/{ }^{*}$-e/ for imperfective and $/{ }^{*}$-o/ for perfective aspect; (ii) a marker of non-finite verb form $/ *$-ka/; and (iii) a marker of middle voice ${ }^{*}$-de- $/$. Proto-Chibchan probably had sov order, along with the following orders of constituents: noun-adjective, noun-numeral, noun-postposition and possessor-possessed. As for the case-marking system, Tunebo /ta $\mathrm{t} /$, Bribri / to/ $(<t \ddot{o}>)$, Cabécar /ti / $(<t \ddot{e}>)$ and Guatuso /ti/ favor the possibility, according to Constenla (2008), of reconstructing an ergative postposition $/ * \mathrm{tV} /$, with an alternation in the vowel portion.

There have been several versions and revisions of the Chibchan family tree. I will refer to the most recent proposal by Constenla (2008: 127), named 'Paya-Chibchan', in Figure 6.2.

As shown in Figure 6.2, Proto Paya-Chibchan includes four branches: Votic, Isthmic, Magdalenic and Paya (which forms its own branch). The languages that concern the present article are Bribri and Cabécar (Viceitic), and only for purposes of comparison Teribe and Térraba (Naso), and Guaymí and Buglere (Guaymiic), all of which are found in the larger Isthmic branch. Peripherally, this article will also refer to Muisca as well as Cuna, Rama, Damana, Paya and Boruca. The choice of languages for syntactic comparison in $\$ 3$ relied on two main criteria: (i) the language belongs to the Isthmic branch and (ii) there are sufficient and accessible materials on the language. ${ }^{6}$

6 My primary sources for Bribri are Constenla et al. (1998) (Свв) and elicitation with the native consultant Alí García Segura (EL), plus Jara Murillo (1993) (Інв) and Jara Murillo \& García Segura (2008) (SOA) as secondary sources; for Cabécar: Margery Peña (1989) (DCE) and the native consultant Severiano Fernández Torres (EL); for Teribe: Quesada (2000) (GT); for Térraba: Constenla (2007) (LT); for Guaymí: Quesada Pacheco (2008) (GG) and Murillo Miranda (2010) (OSN); for Buglere: Quesada (2012) (GB). Besides these, my source for Muisca 


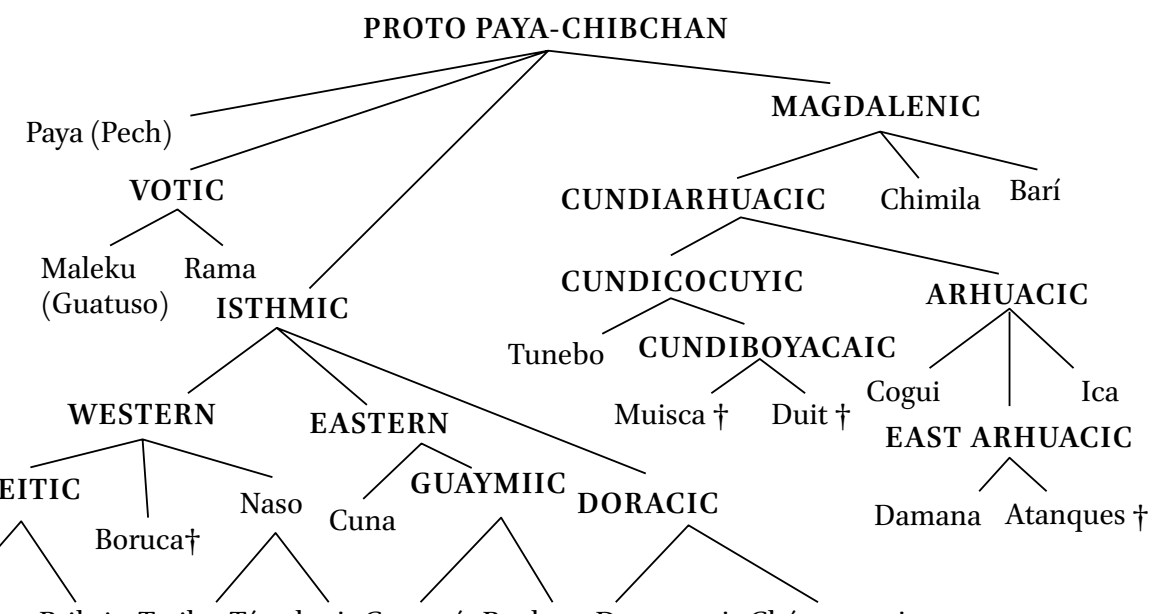

Cabécar Bribri Teribe Térraba † Guaymí Buglere Dorasque $\dagger$ Chánguena†

FIGURE 6.2 Macro-family Paya-Chibchan (reproduced from Constenla 2008: 127)

Both Bribri and Cabécar show an ergative-absolutive alignment system in most areas of simple clause syntax. Word order is rigidly $\mathrm{PV}^{7}$ and the ergative phrase can go either before or after the indivisible PV constituent. In both languages, there is only one set of pronouns for all roles: $\mathrm{S} / \mathrm{P}$ is always unmarked (both NPs and pronouns) and A is case-marked (both NPs and pronouns). Both languages have almost entirely suffixing verbal morphology, but neither has obligatory indexation of A or S/P arguments in the verb. In Bribri, there is optional bound marking of the absolutive category only when it is a 3 rd person plural, animate entity. In Cabécar, verbal morphology can optionally indicate the plurality of S/A in transitive or intransitive clauses and that of $\mathrm{P}$ by means of two different suffixes only in certain tenses and aspects. In both languages, the verbal paradigm is based on voice, active vs. middle, and aspect, perfective vs. imperfective. The canonical ergative marker in Bribri is tö or its allomorphic variants $d \ddot{r} r$ and $r$. Other ergative forms are obtained by the contraction of personal pronouns plus the ergative postposition $t \ddot{o}$ (such as $y \ddot{o}$, formed by the first person singular pronoun $y e^{\prime}$ plus $\left.t \ddot{0}\right)$. In Cabécar, the canonical ergative marker

is mainly Ostler (1994) (STM). Throughout the article, every example includes the abbreviations established in this section along with the page number from where the example was taken, e.g. (GG: 145). The abbreviation is based on the title of a given work (i.e. GG= Gramática de la lengua guaymí).

7 S, A and P are understood here primarily as core syntactic arguments. More specifically, following Comrie (1978), S stands for the sole argument of an intransitive verb; A stands for the most actor-like argument of a transitive verb; P stands for the most patient-like argument of a transitive clause. 
is $t \ddot{e}$ or its variant $t e$. Finally, both languages present the additional ergative marker $w \tilde{a}$, which is not an allomorph of $t \ddot{o}$ or $t \ddot{e} .{ }^{8}$ Constructions in which $w \tilde{a}$ marks the subject in both languages are: possessive predications, the perfect construction, the transitive perfective negative construction and the caused motion construction. In Bribri, the occurrence of this ergative marker is lexically determined with some deponent verbs which take two overt core arguments. In Cabécar, the marker seems to be used in constructions with negative polarity besides the transitive perfective negative. The present article is concerned mainly with the perfect construction and the alienable and inalienable possessive predications, to which we now turn.

In the Coroma variety of Bribri presented in this article, the perfect construction is used to express a past event whose relevance continues into the present time, similarly to the English 'have' perfect. Formally, it is a construction in which $\mathrm{A}$ is marked by the postposition wã , the preverbal $\mathrm{P}$ is unmarked, and the verb shows the suffix -ule as in (13).

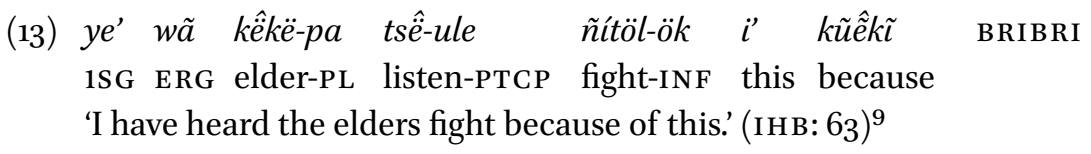

The suffix -ule has been previously described in the literature as a "marker of anteriority" (Margery 1989: lxv, Constenla et al. 1998: 91). I would like to suggest that, outside of the perfect construction, the suffix -ule functions as a past participle. This suffix derives adjectives from verbs (14) and the resulting forms (i.e. participles) have generally the same distributional properties as simple

8 In Bribri, there is a verbal suffix formally identical to the postposition wã. According to some authors, this suffix emphasizes the completion of an action (Jara Murillo \& García Segura 2009: 137), while according to others (Constenla et al. 1998: 27), it indicates a movement of penetration, and conveys an aspectual value of punctuality. Another formally identical suffix -wã can index absolutive animate NPs in the verb. Constenla et al. (1998) claim the existence of another verbal suffix, -wa, meaning descending movement or complete affectedness of the absolutive. Finally, there is an unbound form $w a$, which is the instrumental/ comitative postposition. Some of these forms may be etymologically related to the postposition wã discussed here. Similarly, in Cabécar, $w a$ is the instrumental postposition. Moreover, in Cabécar, the verbal suffix -wã is used in combination with -nã in deriving verbs from adjectives.

9 The glosses of all examples obtained from oral tradition texts are my own. 
adjectives (i.e. they can combine with an existential verb ${ }^{10}$ and modify an NP, as in (15)).

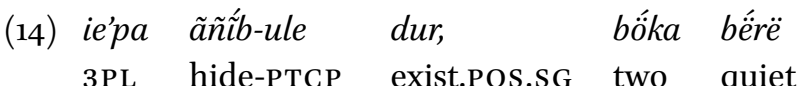
3PL hide-PTCP exist.POS.SG two quiet 'They are standing hidden, both of them quiet.' (IHB: 95) $\begin{array}{lllll}\text { (15) } k \hat{o} & y \ddot{o}-u l e-w \tilde{a} & b u a^{\prime} & k \hat{o} & \tilde{a} \\ \text { mouth } & \text { do-PTCP-CPL } & \text { good } & \text { basket } & \text { in }\end{array}$ BRIBRI 'The well sewed (lit: 'done') mouth of the basket' (IH B: 166)

BRIBRI

In the perfect construction, if the clause is intransitive, $S$ is not marked for case (16).

$\begin{array}{llll}\text { (16) } s a^{\prime} & k a p e ́-u l e & w \tilde{l} & \text { shốó } \\ \text { 1PL.EXCL } & \text { sleep-PTCP } & \text { there } & \text { IDP }\end{array}$

BRIBRI

'We have slept there (points at the mountain).' (soA: 33)

In seeking cognates for the relevant grammatical morphology of this construction, consider another construction also attested in Bribri. The construction in (17) is formally just slightly different from the transitive perfect construction presented in (13).

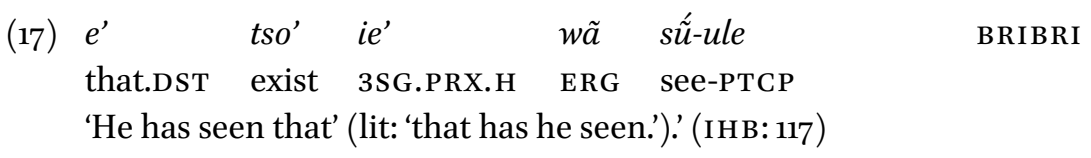

The construction in (17) also appears in the order in (18).
(18) $i e^{\prime}$
$w \tilde{a} \quad e^{\prime}$
tso' sú́-ule
BRIBRI
3SG.PRX.H ERG that.DST exist see-PTCP
'He has seen that.' (EL)

10 In Bribri, there are two existential verbs: $t a^{\prime}$ and $t s o^{\prime}$. Additionally, there is a considerable number of existential verbs which specify the position in which the absolutive argument is found (seated, standing, suspended, lying down, floating, being vertically attached, buried, etc.) (see Constenla et al. 1998: 67, Jara Murillo \& García Segura 20o9: 91). There is also an invariant copula, dör, formally distinct from the existential verbs. 
Moreover, it is possible to use this construction with verbs which imply a change of state, as in (19).
(19) $i e^{\prime}$
$w \tilde{a} \quad k r o ́$
tso' köt-ule
BRIBRI
3SG.PRX.H ERG rooster exist kill-PTCP
'He has a killed/dead rooster.' (EL)

The only formal difference between (13) and (17) is the presence in (17) of the existential tso'. Except for the order in which they appear, all other components are identical: the ergative is marked by wã, the absolutive is unmarked and precedes the existential and the past participle form is stranded at the end of the clause, after the ergative phrase. The meaning of the construction in (17) is perhaps better understood by looking at (19), in which the same construction is used with a change-of-state verb. The meaning of (19) is close to English 'he has a rooster killed', or better said, 'he possesses a rooster that is in the state of having been killed', where the possessor 'he' might or might not be the person who killed the rooster.

Taking into account the order presented in (18) and (19), the constructions in (13) and (15) can be schematized as in Figure 6.3 and Figure 6.4, respectively. The subscripted $i$ indicates that the participial form refers to the state in which the absolutive NP is found.

In §3.1, I will argue that construction A in Figure 6.3 is a later development from construction B in Figure 6.4 and that both originated in a possessive predication. This explains why the case-marking of the perfect construction, in which $\mathrm{A}$ is marked by wã , differs from that of other main clause transitive events, where $\mathrm{A}$ is usually marked by $t \ddot{o}$.

\begin{tabular}{|ccc|}
\hline$[\mathrm{NP}]_{\mathrm{ERG}}$ & {$[\mathrm{NP}]_{\mathrm{ABS}}$} & $\mathrm{V}_{\mathrm{TR} \_\mathrm{PTCP}}$ \\
$\mathrm{NP} w \tilde{a}$ & $\mathrm{NP}_{\mathrm{i}}-\varnothing$ & $\mathrm{V}_{\mathrm{TR}}-u l e_{\mathrm{i}}$ \\
\hline
\end{tabular}

FIGURE 6.3 Construction A (cf. 13)

\begin{tabular}{|cccc|}
\hline$[\mathrm{NP}]_{\mathrm{ERG}}$ & {$[\mathrm{NP}]_{\mathrm{ABS}}$} & EXIST & $\mathrm{V}_{\mathrm{TR} \_\mathrm{PTCP}}$ \\
$\mathrm{NP} w \tilde{a}$ & $\mathrm{NP}_{\mathrm{i}}-\varnothing$ & $t s o^{\prime}$ & $\mathrm{V}_{\mathrm{TR}}-u l e_{\mathrm{i}}$ \\
\hline
\end{tabular}

FIGURE 6.4 Construction B (cf. 15) 


\subsection{From Possession to Perfect Aspect: Bribri}

The purpose of this section is to show that the alienable possessor subject marker $w \tilde{a}$ found in alienable possessive predications was re-analyzed as an ergative marker in the perfect construction. ${ }^{11}$ Therefore, the evolution of a perfect construction from a possessive construction is the mechanism responsible for the innovation of the construction-determined ergative marker wã. The following are the steps that would have taken place, all still attested in Modern Bribri.

Stage o: possession. In alienable possessive predications (20), the verb used in the construction is the existential auxiliary tso' and the possessor must be marked by the postposition wã.

(20) Alí wã kró tso'

BRIBRI

A. PSSR rooster exist

'Alí has a rooster.' (lit: 'Alís rooster exists.') (EL)

The possessor marked by the postposition wã in the alienable possessive predication displays subject properties, just as any S/A argument would. First, it controls co-reference of a 3 rd person anaphoric pronoun in a following possessive NP. In (21), 'house' can refer only to the house of the possessor.

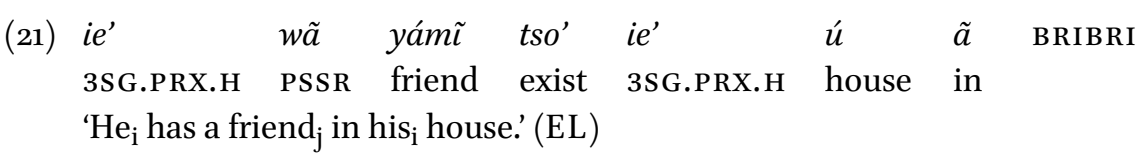

If the house belongs instead to the possessed, the NP 'friend' must be repeated

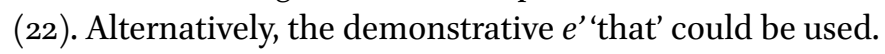

11 An anonymous reviewer suggested to me that, as the discussion immediately below will show, the NP marked by Possessor marker wã behaves as an external possessor. This means that the Possessor NP marked by wã is not a sub-constituent of the possessed NP, but a distinct constituent. Although I acknowledge the validity of this observation, I will refrain from calling $w \tilde{a}$ an external possessor only to avoid possible terminological confusion with extended meanings related to external possession in the typological literature (see for instance, cases of possessor raising included under the broad term 'external possession' in Payne \& Barshi 1999). 
(22) ie' wã yámĩ tso' yámĩ ú $\tilde{a}$

BRIBRI

3SG.PRX.H PSSR friend exist friend house in

'He $\mathrm{i}_{\mathrm{i}}$ has a friend ${ }_{\mathrm{j}}$ at his $\mathrm{j}_{\mathrm{j}}$ house.' (EL) (lit: 'He has a friend at the friend's house.')

Second, the NP marked by wã controls co-reference under coordination as an A argument marked by the ergative postposition tö would (23).

(23) $i e^{\prime}$

wã yámĩ bák bua' ie'

ú $\quad \tilde{a}$ BRIBRI

3SG.PRX.H PSSR friend exist.PST good 3SG.PRX.H house in

ẽnã $i e^{\prime} \quad m \tilde{\imath}-n-\tilde{e}$

and 3SG.PRX.H go-MVC-PFV

' $\mathrm{He}_{\mathrm{i}}$ had a good friend $\mathrm{j}_{\mathrm{j}}$ at his $\mathrm{s}_{\mathrm{i}}$ house, and he $\mathrm{l}_{\mathrm{i}}$ left.' (EL)

If 'the good friend' is the one who leaves the house, there are again two options: the repetition of the NP 'friend' in the coordinate clause or the use of the demonstrative $e^{\prime}$ as in (24).

(24) $i e^{\prime} \quad$ wã yámĩ bák bua' ie' ú a 3SG.PRX.H PSSR friend exist.PST good 3SG.PRX.H house in

ẽnã $\quad e^{\prime} \quad m \tilde{\imath}-n-\tilde{e}$

and that.DsT go-MVC-PFV

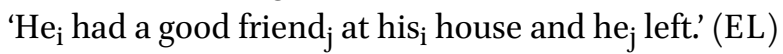

It should be noted that in (23) and (24), wã is an integral and essential part of the construction. If the first coordinate clause were introduced without $w \tilde{a}$, the possessive meaning would be lost and only a predicate attributive reading would be possible (25).
(25) $i e^{\prime}$
yámĩ bák
bua' BRIBRI
3SG.PRX.H friend exist.PST good
'His friend was good.'

The necessity to repeat the NP which is not the possessor to disambiguate cases of co-reference when both A and P are ${ }_{3} \mathrm{SG}$ can be observed also in the caused motion construction.
(26) Alí wã Serveriano mí-n-ẽ
$i e^{\prime}$
ú $\quad \tilde{a}$
BRIBRI
A. ERG S.
go-MVC-PFV 3SG.PRX.H house in
'Alíi took Severiano ${ }_{\mathrm{j}}$ to his $\mathrm{s}_{\mathrm{i}}$ house.' (EL) 
The only possible interpretation in (26) is that the house is Ali's, which is the NP marked by $w \tilde{a}$. If the house belongs to Severiano, the proper name needs to be repeated in the possessive NP as in (27).

$$
\begin{aligned}
& \text { Alí wã Severiano mí-n-ẽ Severiano ú } \tilde{a} \text { BRIBRI } \\
& \text { A. ERG S. go-MVC-PFV S. house in } \\
& \text { 'Alíi took Severiano }{ }_{j} \text { to his } \text { j }_{\mathrm{j}} \text { house.' (lit: 'to Severiano's house') (EL) }
\end{aligned}
$$

Thus, the possessor NP marked by wã displays the subject properties typical of Bribri. In the alienable possessive predication (Figure 6.5), the possessor NP and the possessed NP do not form a single constituent, because the possessor is capable of controlling the reference of an anaphoric pronoun in a conjoined clause, while the possessed NP cannot. ${ }^{2}$

It is worth mentioning that the construction in Figure 6.5 originates from a source other than a transitive predication (i.e. an existential genitive construction of the type 'X's Y exists') and acquires transitive features (i.e. control of co-reference of the subject NP). In this respect, Creissels (2014) argues that diachronically, the transitivization of non-transitive existential possessive predications (including the "genitive" subtype) is widely attested, for instance, in Maltese, Israeli Hebrew and Amharic (cf. also Stassen 2009: $208 \mathrm{ff}$.). In particular, according to Creissels (2013: 469) the possessed, unlike the figure in a spatial relationship, has some similarities to a patient of a prototypical transitive predication in terms of control. For this reason, if an existential construction extends its use to possession, the syntactically ambiguous zero marking of the possessed is reanalyzed as encoding object rather than subject function.

\begin{tabular}{|ccc|}
\hline$[\mathrm{NP}]_{\mathrm{PSSR}}$ & {$[\mathrm{NP}]_{\mathrm{PSSD}}$} & EXIST \\
$\mathrm{NP} w \tilde{a}$ & $\mathrm{NP}-\varnothing$ & $t s o^{\prime}$ \\
\hline
\end{tabular}

FIGURE 6.5 Alienable possessive predication

12 An anonymous reviewer observed that the external possessor status of the NP marked by wã can be contrasted with internal possessors in English. Attributive (NP-internal) possessors in English are not able to bind reflexives. In [John's father] saw himself in the mirror, 'himself' can refer only to father, and never to the NP-internal possessor John's. This clearly contrasts with the subject properties displayed by the subject possessor marked by wã. 
Stage 1: possession of the possessed NP in a modified state. In this stage, the past participle is added after the existential. This verbal form occupies the position of an adjective: both follow the existential verb. As happens in stage $o$, in stage 1 a primary possessive interpretation of the construction is possible if the existential is followed by an adjective, as shown in (28).

(28) $i e^{\prime}$

$\begin{array}{llllll}i e^{\prime} & w \tilde{a} & k r o ́ & t s o ' & \hat{o ̂ j k e ̂ ́ ~} & \text { BRIBRI } \\ \text { 3SG.PRX.H } & \text { PSSR } & \text { rooster } & \text { exist } & \text { fat } & \\ \text { 'He has a fat rooster.' (EL) } & & & \end{array}$

Therefore, in this stage, the alienable possessive predication in stage o can be expanded as shown in Figure 6.6. The adjective after the existential specifies a property of the possessed NP, as indicated by the subscript $i$.

\begin{tabular}{|cccc|}
\hline$[N P]_{\text {PSSR }}$ & {$[N P]_{\text {PSSD }}$} & EXIST & ADJ \\
$\mathrm{NP} w \tilde{a}$ & $\mathrm{NP}_{\mathrm{i}}-\varnothing$ & $t s o^{\prime}$ & ADJ $_{\mathrm{i}}$ \\
\hline
\end{tabular}

FIGURE 6.6 Alienable possessive predication modified by an adjective

The function of the past participle in this construction is identical to that of an adjective in that it modifies the state in which the possessed NP is found, as in (19) repeated as (29).

$\begin{array}{llllll}\text { (29) } i e^{\prime} & w \tilde{a} & k r o ́ & t s o ' & \text { kót-ule } & \text { BRIBRI } \\ \text { 3SG.PRX.H } & \text { PSSR } & \text { rooster } & \text { exist } & \text { kill-PTCP } & \\ \text { 'He has a killed/dead rooster.' (EL) } & & \end{array}$

In this stage, the Possessor marked by wã need not be co-referential with the Agent of the event that led to the state: the possessor might or might not be the one who caused the death of the rooster. A close translation of (29) would be 'he possesses a rooster that is in the state of having been killed'. An example of possessor co-referential with the Agent of the event appears in (30).

$\begin{array}{llllll}\text { (30) } i e^{\prime} & w \tilde{a} & \text { kró } & \text { tso' } & \text { sú́-ule } & \text { BRIBRI } \\ \text { 3SG.PRX.H } & \text { PSSR } & \text { rooster } & \text { exist } & \text { see-PTCP } & \\ \text { 'He has a rooster seen.' (EL) } & & & \end{array}$

Conceivably, in this stage the existential starts to be reinterpreted as an auxiliary: it no longer plays the role of expressing possession as in stage o. Rather, it accompanies the participial form carrying the semantic content of the verb ('kill', 'see'). The construction with the participial verb form in (29) and (30) (cf. 


\begin{tabular}{|cccc|}
\hline$[\mathrm{NP}]_{\mathrm{PSSR}}$ & {$[\mathrm{NP}]_{\mathrm{PSSD}}$} & EXIST & $\mathrm{V}_{\text {TR_PTCP }}$ \\
$\mathrm{NP} w \tilde{a}$ & $\mathrm{NP}_{\mathrm{i}^{-}-\varnothing}$ & $t s o^{\prime}$ & $\mathrm{V}_{\text {TR_ }} u l e_{i}$ \\
\hline
\end{tabular}

FIGURE 6.7 Alienable possessive predication modified by a participle

\begin{tabular}{|cccc|}
\hline$[\mathrm{NP}]_{\mathrm{ERG}}$ & {$[\mathrm{NP}]_{\mathrm{ABS}}$} & $\mathrm{AUX}$ & $\mathrm{V}_{\mathrm{TR} \_\mathrm{PTCP}}$ \\
$\mathrm{NP} w \tilde{a}$ & $\mathrm{NP}_{\mathrm{i}}-\varnothing$ & $t s o$ & $\mathrm{~V}_{\mathrm{TR}^{-}}-$ule $_{i}$ \\
\hline
\end{tabular}

FIGURE 6.8 Perfect construction with auxiliary

Figure 6.7) is identical to the alienable possessive predication modified by an adjective (Figure 6.6).

Probably, this is the transitional stage in which reanalysis covertly takes place. The reanalysis is prompted most likely by cases such as he has a rooster seen' in which the owner of the rooster and the 'seer' must be the same person. Then, co-referentiality is generalized to ambiguous cases such as 'he has a killed rooster/he has killed a rooster'. ${ }^{13}$ Cases such as 'he has a rooster seen' favor the interpretation in which the owner of the rooster and the 'seer' are the same person. Thus, the construction in Figure 6.7 becomes re-analyzed as follows.

Stage 2: from modified possession to perfect aspect. In this stage, the possessive interpretation still possible in stage 1 (cf. (28), (29)) is no longer available. The NP marked by wã is necessarily the Agent, and not necessarily a possessor. The invariant existential auxiliary is dropped, probably because the participial form already carries the semantic information of the event being described. Thus, example (30) of stage 1 'he has a rooster seen', meaning 'he possesses the rooster and he is the one who saw the rooster', comes to mean 'he has seen a rooster' (31).

$\begin{array}{lllll}\text { (31) } i e^{\prime} & w \tilde{a} & \text { kró } & \text { sú-ule } & \text { BRIBRI } \\ \text { 3SG.PRX.H } & \text { ERG } & \text { rooster } & \text { see-PTCP } & \end{array}$

'He has seen a rooster.' (EL)

13 The (possibly odd) English translations 'he has a killed rooster' and 'he has a rooster seen' are not meant to suggest a causative interpretation, but only a 'perfect' interpretation. The constructions presented so far can never be used in Bribri to express a causative event. 


\begin{tabular}{|ccc|}
\hline$[\mathrm{NP}]_{\mathrm{ERG}}$ & {$[\mathrm{NP}]_{\mathrm{ABS}}$} & $\mathrm{V}_{\mathrm{TR}}$ \\
$\mathrm{NP} w \tilde{a}$ & $\mathrm{NP}_{\mathrm{i}^{-}} \varnothing$ & $\mathrm{V}_{\mathrm{TR}}-u l e_{i}$ \\
\hline
\end{tabular}

FIGURE 6.9 Perfect construction without auxiliary

The meaning of the construction at this point is only about aspect: it conveys the idea of an action that occurred in the past, but with relevance in the present. The perfect construction with the auxiliary of stage 1 (Figure 6.8) becomes the perfect construction without the auxiliary in Stage 2 (Figure 6.9).

As in previous stages, in stage 2 the ergative NP marked by $w a \tilde{a}$ continues to display Subject properties, such as control of co-reference under coordination (32).

(32) Alí wã aláköl pakló-ule ẽnã ie' ulú-n-ẽ BRIBRI A. ERG woman hug-PTCP and 3SG.PRX.H become.angry-MVC-PFV 'Alí ${ }_{i}$ has hugged the woman $_{j}$ and (then) $h_{i} /{ }^{*}$ she $_{j}$ became angry.' (EL)

An additional test which shows a clear S/A pivot in some areas of Bribri's syntax, and thus serves to show subject properties of the NP marked by $w \tilde{a}$, is found outside main clauses (Dickeman Datz 1984: 124 ff.). An embedded complement clause (CC) in absolutive position (33) can be moved to the right, leaving in its place the resumptive absolutive pronoun $i(34)$.

(33) $y e^{\prime}$ wã [Alí wã kró kót-ule $\left.e^{\prime}\right]_{\mathrm{CC}}$ sú-ule BRIBRI 1SG ERG A. ERG rooster kill-PTCP that.DST see-PTCP

'I have seen that Alí has killed the rooster.' (EL) (lit: 'I (that) Alí has killed the rooster that I have seen.')

(34) $y e^{\prime}$ wã $\tilde{\imath}$-sú́-ule $\quad[\text { tö Alí wã kró kót-ule }]_{\mathrm{CC}}$ BRIBRI 1SG ERG 3SG-See-PTCP COMPL A. ERG rooster kill-PTCP 'I have seen that Alí has killed the rooster.' (EL) (lit: 'I have seen it that Alí has killed the rooster.')

The S/A argument of the postposed clause, i.e. Alí in (34), can be raised to become the absolutive within the matrix clause (35). When this happens, the S/A argument of the complement clause, which has become the absolutive in the matrix clause, leaves a zero in the complement clause and the verb appears in its infinitive form. ${ }^{14}$

14 This is true only for certain verbs of perception and cognition (i.e. 'see'). Other verbs retain their conjugated form in the complement clause after the S/A argument has been raised. 

(35) ye' wã Alí sú́-ule $\quad[\varnothing \quad k r o ́ \quad t t \text {-ók }]_{\mathrm{CC}} \quad$ BRIBRI 1SG ERG A. see-PTCP rooster kill-INF
'I have seen Alí killing roosters.' (EL)

As shown in examples (33) to (35), the NP marked by the ergative postposition wã behaves in the same way as an NP marked by the ergative postposition tö would (see Dickeman Datz 1984: 123 ff. for equivalent examples with tö in the transitive complement clause and for examples with an unmarked $S$ in the intransitive complement clause).

The evolution of the perfect construction from the alienable possessive predication seems to be a recent innovation in Bribri: all the stages of the reanalysis are still synchronically present in the language. The stages and constructions of each stage are summarized in Table 6.1.

TABLE 6.1 Evolution of the perfect construction from the alienable possessive predication

\section{Stage Meaning Cognate constructions}

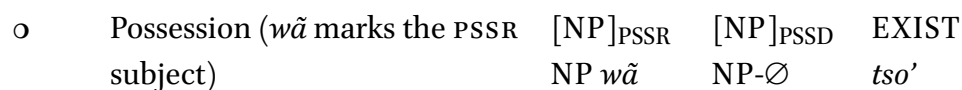

possession + modifier (adj)

$\begin{array}{llll}{[\mathrm{NP}]_{\text {PSSR }}} & {[\mathrm{NP}]_{\text {PSSD }}} & \text { EXIST } & \text { Adj } \\ \text { NP } w \tilde{a} & \mathrm{NP}^{-} \varnothing & t s o^{\prime} & \text { Adj }\end{array}$

$1 \quad$ Possession of the possessed NP

$[\mathrm{NP}]_{\text {PSSR }} \quad[\mathrm{NP}]_{\mathrm{PSSD}} \quad$ EXIST $\quad \mathrm{V}_{\mathrm{TR} \_\mathrm{PTCP}}$ $\begin{array}{lllll}\text { in a modified state }(\mathrm{PTCP}) & \mathrm{NP} w a & \mathrm{NP}_{\mathrm{i}}-\varnothing & t s o^{\prime} & \mathrm{V}_{\mathrm{TR}}{ }^{\prime} u l e_{i}\end{array}$

Resultative meaning

Possible co-referentiality of A

and PSSR

$[\mathrm{NP}]_{\mathrm{ERG}} \quad[\mathrm{NP}]_{\mathrm{ABS}}$

AUX $\quad \mathrm{V}_{\mathrm{TR}}$

wã marks the PSSR subject who

NP wã $\quad \mathrm{NP}_{\mathrm{i}^{-}} \varnothing \quad$ tso' $^{\prime} \quad \mathrm{V}_{\mathrm{TR} \_}$ule $e_{i}$

might also be $\mathrm{A}$

$2 \quad$ Modified possession becomes

$[\mathrm{NP}]_{\text {ERG }} \quad[\mathrm{NP}]_{\mathrm{ABS}} \quad \mathrm{V}_{\mathrm{TR}}$

perfect aspect

$\mathrm{NP} w \tilde{a} \quad \mathrm{NP}_{\mathrm{i}^{-}} \varnothing \quad \mathrm{V}_{\mathrm{TR} \_}$ule $e_{i}$

wã marks A, which might also

be PSSR

Loss of existential/auxiliary

Only possible reading is past

tense with present relevance 
The main argument to support the directionality presented in this section is based on similar attested directions of change. In this respect, Heine \& Kuteva (2006) argue for the evolution of perfects from possessive constructions based on the Action schema [X has Y] in several branches of Indo-European (Italic, Germanic, Celtic, Albanian, partially Slavic and Baltic) and in some non-IndoEuropean languages spoken in Europe (e.g. Finnish). Other examples in the literature of perfects diachronically deriving from possessive constructions include: Benveniste (1966), who describes the origin of the transitive perfect in Classical Armenian from a possessive construction, and Haig (2008), who argues for the emergence of ergativity in Middle Iranian from external possession.

Along the same line, Trask (1979: 398) claims that ergative syntax has arisen from possessive sources in Kurdish, Middle Persian, Old Armenian, Eskimo-Aleut and North and South Caucasian languages. In particular, Trask argues that while 'Type A' ergativity results from a passive made obligatory, 'Type B' ergativity "results from the incorporation into the inflectional paradigm most often of a stative de-verbal adjective, incorporated by means of a possessive construction" (1979: 402). More specifically, in Trask's view, Type B ergativity depends on the existence, in a given language, of a de-verbal adjective, sov word order (this correlation remains unexplained) and the lack of a verb 'have'. Crucially, in European languages in which stative de-verbal adjectives became part of the verbal system through initially possessive predications, no Type B ergativity arose due to the presence of a verb 'have' in the construction, whose possessor was coded as nominative and remained such when it was reinterpreted as subject in the new perfect construction.

However, according to Trask, in languages that lack a verb 'have', possessive predications very often feature an overtly marked possessor expressed by an oblique case - usually genitive, dative or locative. The reanalysis of such a possessor marker as an agent would then bring about ergative case marking. Therefore, a clause of the shape To me/of me/at me (is) a window broken being reinterpreted as 'I have broken a window' would inevitably lead to Type B ergativity. This depicts exactly the features of Bribri, a language with a participle which can function as a de-verbal adjective, no 'have' verb, sov order and an overtly marked possessor in possessive predications. ${ }^{15}$

A second main argument in support of the directionality outlined here is that in closely related languages such as Cabécar, a similar pattern of reanalysis can be observed. Arguably, the long-lasting language contact and

\footnotetext{
15 While beyond the scope of the present article, it should be noted that Type B ergativity has been extended to several other constructions in this language where it now competes with the canonical ergative marker $t \ddot{t}$.
} 
intermarriage between these two communities might have favoured a similar reanalysis. ${ }^{16}$

\subsection{From Possession to Perfect Aspect: Cabécar}

In Cabécar, wã marks both alienable (36) and inalienable (37) possessor subjects.

$\begin{array}{lllll}\text { (36) yís } & w a \tilde{a} & \text { jóshkoro } & \text { tsó́ } & \text { CABÉCAR } \\ \text { 1SG } & \text { PSSR } & \text { rooster } & \text { exist } & \end{array}$

'I have a rooster.' (EL)

(37) yís wã kutá tsố tkếl CABÉCAR
1SG PSSR sister exist four
'I have four sisters.' (DCE: 310 )

The meaning of past perfect or pluperfect tense/aspect is expressed by the following construction. ${ }^{17}$

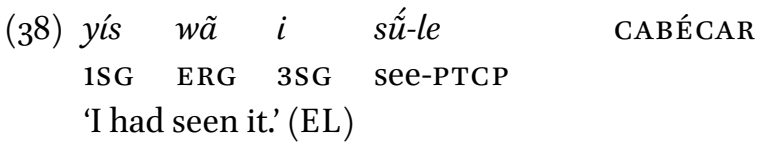

The construction in (38) is identical in all its constituent parts to that of Bribri (cf. (31)). The meaning, however, is past rather than present perfect. Don Severiano Fernández Torres (p.c.) indicates that a construction such as (39) is most likely to be used by elders nowadays rather than by younger generations. This is because the construction is somewhat archaic due to the presence of the existential tsố. The meaning of (39) is closer to 'I had it in the state of being seen'.

16 Constenla \& Ibarra (2009) reconstruct the approximate distribution of the indigenous languages and people of Costa Rica and border areas of Nicaragua and Panama before the arrival of the Spanish conquerors. Bribri and Cabécar have been spoken in contiguous areas of the Talamanca mountain chain since the XVIth century and still are nowadays.

17 The examples offered by Margery (1989) of perfect constructions in Cabécar are different in structure from those presented here. I have presented a native speaker of Cabécar (Don Severiano Fernández Torres) with the data concerning perfect constructions found in Margery (1989: lxxix) and he expressed that those are not in fact perfect constructions but rather constructions with an aspectual meaning that differs from the perfect. The Cabécar examples in this section are the result of elicitation with Don Severiano Fernández Torres. It must be noted that Don Severiano Fernández Torres also speaks Bribri. 


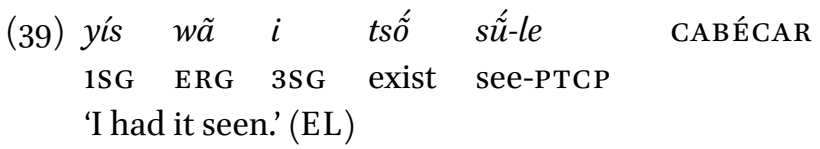

By comparing (38) and (39) with Bribri examples presented in the previous sections, it is possible to identify the following lexical and morphological cognates: (i) in both languages the possessor marker is wã ; (ii) the existential is tso' in Bribri and tsố in Cabécar; and (iii) the morpheme suffixed to the verb to make a participle is -ule in Bribri and -le in Cabécar. The order in which the elements appear in the perfect constructions is also identical: A precedes $\mathrm{P}$ which is followed by a verb phrase composed of the existential (later dropped) plus the participial form of the verb. Therefore, in a language with a possessive predication identical to that of Bribri, we also find an identical perfect construction which conveys a past perfect meaning. This suggests a coincident path of reanalysis. In Cabécar, the source construction could have been either the alienable or inalienable possessive predication, given that both host a marked possessor.

However, the reanalysis in Cabécar yielded a construction which conveys past perfect meaning. The present perfect construction in this language (40) raises questions.

(40) yís të $\quad i \quad$ sú-le
1SG ERG $\quad$ 3SG $\quad$ see-PTCP
'I have seen it.' (EL)

This construction is formally identical to the one presented in (38), which expresses a past perfect meaning, except that it contains the canonical ergative marker $t \ddot{e}$ instead of $w \tilde{a}$. As in the case of the past perfect construction, (41) is possible albeit archaic according to the synchronic intuition of the speaker.

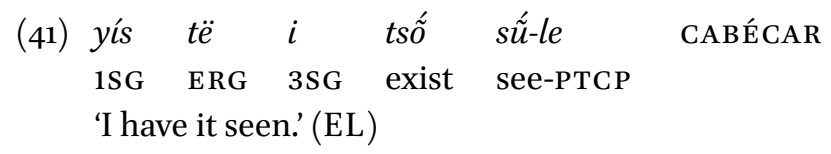

The difference between present and past perfect constructions in Cabécar relies on the choice of the ergative marker: $w \tilde{a}(38-39)$ for past perfect and $t \ddot{e}$ (40-41) for present perfect. As in Bribri, a participle which becomes a main verb, as in (38) and (40), has its origin in an originally more complex construction, which featured an existential/auxiliary. The construction in (41) possibly originated on the basis of the structure in (39). The post-reanalysis 
non-canonical ergative marker wã was replaced via analogical extension: the canonical ergative marker të extends into the construction. This created two competing constructions from a single source, which somehow acquired two distinct meanings, i.e. past and present perfect. Afterwards, the existential was dropped and the participle became the main verb in both constructions. The shift of meaning from present to past perfect for the construction that uses $w \tilde{a}$ as an ergative marker (38) is not fully comprehended at this point, but it is presumably due to competition with the perfect construction that has the canonical ergative marker $t \ddot{e}$.

As expected, evidence from possessive predications and perfect constructions found in the sister language Cabécar corroborates the direction of reanalysis posited for Bribri in §3.1. These facts invite the assumption that before the split into two distinct languages, Proto-Viceitic had a perfect construction such as that in Figure 6.10.

Obviously, there must also have been in the ancestor language some sort of possessive predication in which the adjective or the participial verb form modifying the state of the possessed NP was optional, as in Figure 6.11.

\begin{tabular}{|cccc|}
\hline$[N P]_{\text {ERG }}$ & {$[N P]_{\text {ABS }}$} & EXIST & $\mathrm{V}_{\text {TR-PTCP }}$ \\
$N P$ *wã & $\mathrm{NP}_{\mathrm{i}^{-}} \varnothing$ & *tsõ & $\mathrm{V}_{\text {TR- }_{-}}$ule $_{\mathrm{i}}$ \\
\hline
\end{tabular}

FIGURE 6.10 Perfect construction of Proto-Viceitic ${ }^{18}$

\begin{tabular}{|cccc|}
\hline$[N P]_{\text {PSSR }}$ & {$[N P]_{\text {PSSD }}$} & EXIST & $\left(\mathrm{ADJ}_{\mathrm{i}} / \mathrm{V}_{\text {TR_PTCP }}\right)$ \\
$\mathrm{NP}{ }^{*}$ wã & $\mathrm{NP}_{\mathrm{i}}-\varnothing$ & *tsõ & $\left(\mathrm{ADJ}_{\mathrm{i}} / \mathrm{V}_{\text {TR- }_{-}}{ }^{*} \mathrm{ule}_{\mathrm{i}}\right)$ \\
\hline
\end{tabular}

FIGURE 6.11 Optionally modified possessive construction of Proto-Viceitic

18 The reconstruction of *tsõ is disputable. The problem is obviously the final vowel, which is nasalized and with high tone in Cabécar (tsố), but oral in Bribri, followed by a glottal stop $\left(t s o^{\prime}\right)$. According to Constenla (1981: 183), the reflexes of proto-nasality were maintained in all environments in both languages. As a consequence, the loss of nasality in Bribri needs to be explained. A possible explanation is offered by Constenla, who argues that cases in which a language presents the expected reflex of proto-nasality and the other does not "can be explained as resulting from analogic changes which have incorporated a stem derived by means of $\left.\right|^{* \sim} /$ into the class of stems consisting of a root without any stem formative or of a root plus another stem formative, or vice versa" (1981: 181). Thus, my proposed reconstruction assumes that Bribri tso' is the result of analogical replacement of the proto-nasality stem formative by the /-P/ stem formative. 
The conclusion reached at the end of this section is that the ergative marker $w \tilde{a}$ arose from the possessor marker wã. The next section intends to show that this evolution can be claimed through undisputable cognacy among constructions.

\subsection{Corroborating Actual Cognacy among Constructions}

After the analysis put forth in $\S 3.1$ and $\S 3.2$, one might argue that this is merely a case of seeing similarities within constructions and imposing a hypothetical scenario of reanalysis based on constructions that are not demonstrably cognates. The purpose of this section is to show that in fact this argumentation can be proven correct if we examine each of the individual pieces which appear in the constructions under investigation. We started out with construction A (Figure 6.3), i.e. the perfect construction without an auxiliary (repeated as Figure 6.9), and construction B (Figure 6.4), the perfect construction with an auxiliary (repeated as Figure 6.8).

Two fundamental pieces that constructions A and B have in common are the ergative marker $w \tilde{a}$ and the suffix -ule. We should then inquire where else in the grammar we find modern reflexes of each of these two components. We saw that the latter component is a participle which behaves much like an adjective, cf. (14) and (15). As for the former component, the postposition $w \tilde{a}$ is found in the alienable possessive predication (Figure 6.5), which also features the existential tso. This construction can be modified by an adjective (Figure 6.6) or by a participle (Figure 6.7). The construction in Figure 6.7 is formally identical to the construction in Figure 6.4.

A fair question to posit at this point is the nature of the relationship between all these constructions. Given the extensive similarity in form, one possibility is that they are simply synchronic variants of one another, that is, they are all synchronically the same construction. However, the semantics of the perfect construction (Figure 6.3, Figure 6.9) are quite different from the possessive semantics of the other constructions (Figures 6.4-6.8), and this shift in semantics correlates with the presence versus absence of one formal element, the existential verb tso'. As such, it appears necessary to posit at least two distinct constructions synchronically. On the other hand, their near identity in form, both morphological and syntactic, can hardly be considered a product of chance - they must come from a common origin, that is, they must be cognate.

Accepting that constructions A and B share a common source, there are three logical possibilities: (i) the alienable possessive predication came from the perfect construction; (ii) the perfect construction came from the alienable possessive predication; or (iii) both the alienable possessive predication 
and the perfect construction came from some third source. The third possibility remains out of the available evidential range. The other two possibilities entail different directions of change. A reasonable way to provide an answer to the issue of directionality is to consider which directions of change are attested in the literature when both perfect constructions and some sort of possessive predications are cognate. As argued in §3.1, the only attested direction of change points to possibility (ii). By relying on this attested direction of change, $\S 3.1$ has posited directionality for the cognate constructions presented in this section.

Now that the synchronic syncretism between the possessor marker and the ergative marker has been explained, we can turn to the second question set forth in the introduction: the ultimate source of the Possessor marker wã. The underlying possession schema of the alienable possessive predication in Bribri and Cabécar seems to be the Genitive schema [X's Y exists] (Heine 1997). However, there is not any readily available synchronic source for this possessor marker in Bribri or Cabécar. This means that wã does not serve, synchronically, other functions besides marking possessor and ergative case in these two languages. This postposition is not used, for instance, to express Source, Location, Goal, Comitative or Instrumental meanings, which would possibly have linked it to other possession schemas proposed by Heine (1997). ${ }^{19}$

The absence of an expected synchronically available source in both languages invites comparison among other languages of the Isthmic branch. The purpose of the next section is to discover, on the basis of historical and comparative evidence, if the postposition wã is found in cognate forms in languages within the larger Isthmic branch, and if so, with what functions.

\section{Alienable Possessive Predications in the Isthmic Branch}

The alienable possessive predication cognate in Bribri and Cabécar clearly reconstructs to Proto-Viceitic (see §3.2). Now the question is whether there

\footnotetext{
19 In Bribri, Source is expressed by the postposition mĩk, Location and Goal by the postposition $\tilde{a}$, Comitative meaning by the postposition $t \tilde{a}$ and instrumental by wa. In Cabécar, Goal is expressed by the postposition $\tilde{\imath} \tilde{a}$, Location is expressed by the postposition ska or $n a$, Comitative meaning by the postposition $d a$, Instrumental by $w a$ and Source by the postposition mĩ. It is evident that the instrumental postposition wa in both languages looks a lot like wã. However, nasality was distinctive in Proto-Chibchan (Constenla 1981) and languages that have a cognate form of wã, such as Guaymí, have be and biti as a comitative and instrumental postpositions, respectively (Quesada Pacheco 20o8: 81).
} 
exists a similar construction in other languages within the Isthmic group and whether such a construction features a cognate form of the Possessor Subject marker wã.

As the attentive reader will know by now, the alienable possessive predication of Bribri looks like (42).

(42) $y e^{\prime} \quad w \tilde{a} \quad$ báka tso' BRIBRI
1SG PSSR cow exist
'I have a cow.'

In this respect, it should be noted that Constenla \& Margery (1979: 33) and Constenla et al. (1998: 105) report for Bribri an example identical to (42) but with the verb $t \tilde{a}$ ' 'exist' as the main predicate. However, Alí García Segura (p.c.) argues that if $t \tilde{a}$ ' is used, the construction in (42) would be slightly unusual in terms of its semantics. It would mean something close to 'I have one exemplar of cow and I am not going to sell it, rather I keep it to show it to people'. Because of this semantic awkwardness, it seems that in the Coroma variety of Bribri the verb used in alienable possessive predications can be only the existential $t s o$ ' or its positional variants, i.e. tchër in (43). The alienable possessor subject must be marked by the postposition wã.

$\begin{array}{llll}\text { (43) } \begin{array}{l}\text { e } \\ \text { person }\end{array} \quad \text { PSSR } & \text { rooster } & \text { exist.POS.SG } \\ \text { 'The person [the king of the dogs] had a rooster.' (IH B: 198) }\end{array}$

In Cabécar, on the other hand, both existentials tã and tsố can be used to express alienable possessive relations. In this case too, the alienable possessor subject is marked by means of the postposition $w \tilde{a}$, as in (44) and (45).

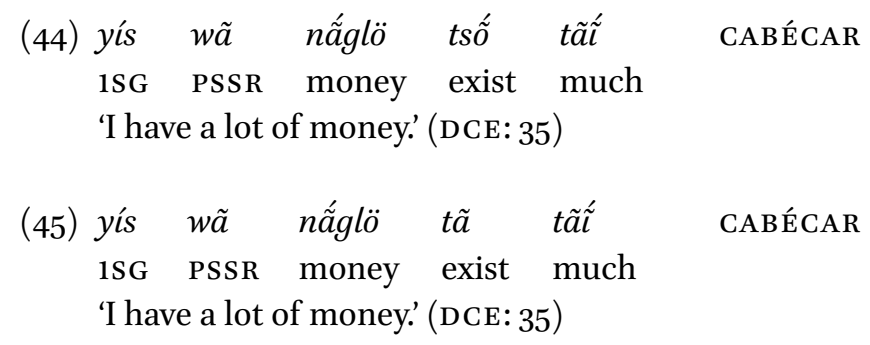

In Guaymí, alienable possessive predications are verbless. The orders possessed-possessor or possessor-possessed (Quesada Pacheco 2008: 72) can 
be used to express alienable possession. With both orders, the possessor is marked with the genitive case marker gwe, cf. (46) and (47). ${ }^{20}$

(46) Chiti gwe nu krämä GUAYMÍ

Chiti PSSR dog three

'Chiti has three dogs.' (or: 'the three dogs of Chiti') (GG: 141)

(47) mädä bänrabe ti gwe GUAYMí

horse nice 1SG PSSR

'I have a nice horse.' (or: 'my nice horse') (GG: 141)

There is a third strategy in Guaymí to mark alienable possession: the order possessor-possessed, in which the possessed is marked by a morpheme identical to the dative marker, namely $e$. However, (46) and (47) are the only two possibilities listed by Quesada Pacheco (2008) to build an alienable possessive predication in Guaymí. This seems to suggest that the Guaymí construction possessor possessed followed by $e$ is used only in attributive possession and not in possessive predication. ${ }^{21}$

In Buglere, existential and possessive constructions are built without any verb overtly expressed in the clause (Quesada 2012: 85). In this language, the alienable possession relation can be expressed by two different strategies: (i) with the order possessor-possessed plus a possessive suffix $-a \sim-i a$ on the possessed (48); or (ii) with the order possessor-possessed plus the genitive postposition no marking the possessor (49).

(48) cha chunu-a

BUGLERE

1SG pig-POss

'My pig' (or: 'I have a pig.') (GB: 75)

(49) chunu cha no

BUGLERE

pig $1 \mathrm{SG}$ GEN

'My pig' (or 'I have a pig.') (GB: 75)

$20 \quad$ The grapheme ä corresponds to [э] in Guaymís orthography.

21 Miguel Angel Quesada Pachecho informs me that several Chibchan languages have a postposed genitive marker in attributive possession (i.e. in possessive NPs). This marker is similar in several languages, among these: Guaymí $e$ (or $i$ ), Teribe $\tilde{\imath}$ (see below), Cabécar and Bribri $-i$ (sometimes with vowel harmony, cf. Bribri kal 'tree' > keli 'a tree of $\mathrm{X}$ ') and Muisca $-e$. This issue will not be addressed here, as the section deals with possessive predications. 
In other languages of the Isthmic group, such as Teribe and Térraba, the alienable possessor is not marked by any postposition. In Teribe (Quesada 200o), there are two sets of personal pronouns: "nominative" and "oblique". The possessive pronouns used in attributive possession are the oblique pronouns (50). However, in order to have a possessive predication, the pronouns from the nominative paradigm must be used for the possessor subject (51). The order in attributive possession and the possessive predication is possessorpossessed. As in Guaymí and Buglere, possessive predications do not contain an overtly expressed verb.
(50) bor $u$
1SG.OBL house
TERIBE
'My house' (adapted from GT: 55)

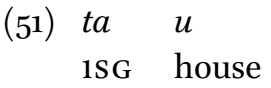
TERIBE
'I have a house.' (adapted from GT: 141)

Another strategy used only to express alienable possession in Teribe is the marker $\tilde{\imath}$, which functions also as a copula. This marker is used only with full NPs when the possession relation being predicated is alienable as in (52). In this case, the order is possessed-possessor.

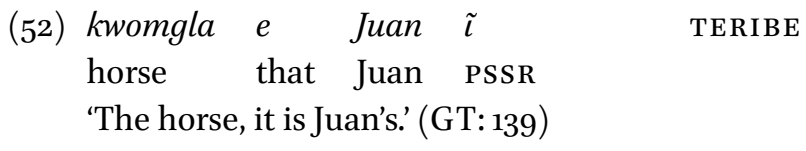

In Térraba, the same phenomenon described for Teribe occurs: one of the two sets of pronouns present in the language is used for attributive possession but not for possessive predication. This set, called "non-focusable" (Constenla 2007), appears to be cognate with Quesada's (2000) "oblique" set. According to Constenla (2007), in the case of alienable possessive predications both the "focusable" (Quesada's "nominative") and "non-focusable" (Quesada's "oblique") sets of pronouns can be used with different nuances in meaning, as in (53) and (54). Finally, the existential in possessive predications is often dropped (55).

(53) t'a cuomgrá t'óc c'ue shcó TÉRRABA
1SG horse
exist that in

'I have horses there.' (LT: 128) 
$\begin{array}{lllll}\text { (54) bor } & \text { cuomgrá tóc c'ue shcó TÉRRABA } \\ \text { 1SG.NF } & \text { horse } & \text { exist that in }\end{array}$ 'There are horses of mine there.' (LT: 128)

$\begin{array}{cll}\text { (55) t'a } & \text { cuomgrá } & \text { c'robö } \\ \text { 1SG } & \text { horse } & \text { two }\end{array}$

TÉRRABA

'I have two horses.' (adapted from LT: 128)

The structure of alienable possessive predications in Guaymí, Buglere, Teribe, Térraba, Bribri and Cabécar is summarized in Table 6.2.

Table 6.2 shows that the cognate alienable possessive predications found in the Viceitic subgroup have some structural similarities with other languages within the Isthmic branch. All the languages in Table 6.2 display the order possessor-possessed. Some also allow the order possessed-possessor. In particular, in Guaymí, Buglere and Teribe when the order is possessed-possessor, the latter retains extra morphological marking and no verb is used in the possessive predication. None of the languages outside the Viceitic group requires the presence of a verb to form a possessive predication. Finally, Térraba is the only language that optionally builds a possessive predication with

TABLE 6.2 Alienable possessive predications within the Isthmic group

Alienable possessive predications

\begin{tabular}{|c|c|c|c|c|c|c|c|}
\hline \multirow[t]{4}{*}{ Guaymiic } & \multirow[t]{2}{*}{ Guaymí } & $\mathrm{NP}_{\text {PSSR }}$ & \multicolumn{2}{|l|}{$\mathrm{NP}_{\mathrm{PSSD}}$} & $\mathrm{NP}_{\text {PSSD }}$ & \multicolumn{2}{|l|}{$\mathrm{NP}_{\text {PSSR }}$} \\
\hline & & NP gwe & $N P-\varnothing$ & & $N P-\varnothing$ & NP gwe & \\
\hline & \multirow[t]{2}{*}{ Buglere } & $\mathrm{NP}_{\mathrm{PSSR}}$ & $\mathrm{NP}_{\mathrm{PSSD}}$ & & $\mathrm{NP}_{\text {PSSD }}$ & $\mathrm{NP}_{\text {PSSR }}$ & \\
\hline & & $N P-\varnothing$ & NP $a$ & & $N P-\varnothing$ & NP no & \\
\hline \multirow[t]{4}{*}{ Viceitic } & \multirow[t]{2}{*}{ Bribri } & $\mathrm{NP}_{\text {PSSR }}$ & $\mathrm{NP}_{\mathrm{PSSD}}$ & EXIST & \multirow[t]{2}{*}{-} & & \\
\hline & & $\mathrm{NP} w \tilde{a}$ & $N P-\varnothing$ & $t s o^{\prime}$ & & & \\
\hline & \multirow[t]{2}{*}{ Cabécar } & $\mathrm{NP}_{\mathrm{PSSR}}$ & $\mathrm{NP}_{\mathrm{PSSD}}$ & EXIST & $\mathrm{NP}_{\mathrm{PSSR}}$ & $\mathrm{NP}_{\text {PSSD }}$ & EXIST \\
\hline & & $\mathrm{NP} w \tilde{a}$ & $N P-\varnothing$ & $t s o \tilde{~}$ & $\mathrm{NP} w \tilde{a}$ & NP- $\varnothing$ & $t \tilde{a}$ \\
\hline \multirow[t]{4}{*}{ Tiribí } & \multirow[t]{2}{*}{ Teribe } & $\mathrm{NP}_{\mathrm{PSSR}}$ & $\mathrm{NP}_{\mathrm{PSSD}}$ & & $\mathrm{NP}_{\mathrm{PSSD}}$ & \multirow{4}{*}{$\begin{array}{l}\mathrm{NP}_{\mathrm{PSSR}} \\
\mathrm{NP} \tilde{\imath}\end{array}$} & \\
\hline & & $N P-\varnothing$ & $N P-\varnothing$ & & $N P-\varnothing$ & & \\
\hline & \multirow[t]{2}{*}{ Térraba } & $\mathrm{NP}_{\text {PSSR }}$ & $\mathrm{NP}_{\mathrm{PSSD}}$ & (EXIST) & - & & \\
\hline & & $N P-\varnothing$ & $N P-\varnothing$ & t'óc & & & \\
\hline
\end{tabular}




\begin{tabular}{|lcc|}
\hline$[N P]_{\text {PSSR }}$ & {$[N P]_{\text {PSSD }}$} & EXIST \\
$\mathrm{NP}$ *wã & $\mathrm{NP}_{\mathrm{i}}-\varnothing$ & *tsõ \\
\hline
\end{tabular}

FIGURE 6.12 Alienable possessive predication of Proto-Viceitic

an existential verb. Given the evidence available in Table 6.2, the Alienable Possessive Predication of Bribri and Cabécar in Figure 6.12 can only be plausibly reconstructed to Proto-Viceitic.

Two questions led this section: (i) whether wã is present in other Isthmic languages and (ii) whether these languages have an alienable possessive predication similar or identical to that of Bribri and Cabécar. The answer to latter question is obviously no, while the answer to the former is maybe.

In terms of potentially cognate elements among languages in this sample, one should take into account case markers on the possessor and the presence of existential verbs. Case markers present on the possessor are: Bribri and Cabécar wãa, which are identical cognates, Guaymí gwe which could be cognate with wãa, Buglere no, which does not seem to be cognate, and Teribe $\tilde{\imath}$, which also does not seem to have enough phonological similarity to be cognate with either wã or gwe. As for the existentials, potential cognacy could be argued for tso' (Bribri) and tsố (Cabécar) with t'oc (Térraba), which is phonetically [t’ók]. ${ }^{22}$ By positing the existence of a /*ts/ sequence in the proto-language, the reflexes would be /ts/ in Bribri and Cabécar and /z/ in Térraba before /*a/ or /t $\mathrm{t} /$ before $/ * \mathrm{i} /$ and $/ * \mathrm{u} /$ (Constenla 1981: 241). It is worth noting, however, that Constenla finds only one etymology for this sequence in Térraba and the vowels that follow the sequence do not include $/{ }^{*} \mathrm{o} /$, which is the one needed for this particular reconstruction. For this reason, it is not possible to determine whether these forms are in fact cognates.

As for the other existential, it is worth comparing Cabécar tã (and Bribri $t \tilde{a}$, although not used in alienable possession) with the verb tä in Guaymí, meaning 'be, stay', which is phonetically [to]. There is another set of words which un-

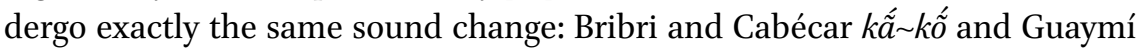
$k a ̈$ 'place'. Constenla (1981: 277, 283) actually reconstructs the form for 'time, space' for Proto-Chibchan as *ka. Thus, even if tä is not used to build alienable possessive predications in Guaymí, the cognate forms tã in Cabécar and $t \tilde{a}$ ' in Bribri could be reflexes of a proto-form *ta which has probably undergone a semantic shift from 'be, stay' to 'exist' in the Viceitic languages.

22 The glottalization of $t^{\prime}$ [t?] in Térraba is not predicted by regular sound change and would therefore have to be considered idiosyncratic. 
Given this evidence, and considering that the comparison shows only a feeble possibility of cognacy between $w \tilde{a}$ and gwe as possessor markers, one might conclude at this point that the alienable possessive predication of Proto-Viceitic was probably an innovation within this subgroup, either parallel in Bribri and Cabécar or influenced by language contact between these bordering languages. This speculation abides by the principle of parsimony, also known as Occam's razor: since a certain feature is attested only in a single clade within a given sub-branch, the uniqueness of this feature finds its "simplest" explanation in innovation.

This reasoning is, nevertheless, challenged by an inherent contradiction. The argument of innovation claims that $w \tilde{a}$ is a 'new' piece of grammar which was not present in the proto-language. It follows from this statement that the source for this innovation should be readily available: we should find synchronic evidence for the origin of this postposition in the languages that have it, or somewhere else within the languages of the Isthmic branch. As we saw in this and the previous section, this is not the case: no synchronic source can be found for wã. In addition to this, the alienable possessor marker gwe in Guaymí could in fact be cognate with the alienable possessor marker wã in Bribri and Cabécar. If this were the case, independent, parallel innovation could be posited for two clades, Guaymiic and Viceitic, to avoid abandoning the argument of parsimony. Alternatively, one could posit the loss of this morpheme in all other languages within the branch, so that Guaymiic and Viceitic would become the conservative sub-branches.

Determining whether wã is in fact cognate with Guaymí gwe is pivotal to allow one to choose between innovation and conservatism. As happens in Bribri and Cabécar, gwe in Guaymí does not seem to have an immediate synchronic source or to be related to other postpositions present in the language (Quesada Pacheco 2008: 80-86). Similarly to the Viceitic languages, gwe in Guaymí, at least in the variety of Panama, is also an ergative marker.

Based on additional comparative data from Muisca, a Chibchan language from Colombia, I will argue that: (i) Guaymí gwe and Bribri and Cabécar wã are in fact cognates; (ii) they most likely come from a noun meaning 'something', 'thing', 'property' or 'belonging'; and (iii) the argument of conservatism is better grounded than the argument of innovation.

Muisca is a Chibchan language of the Magdalenic branch, a sister branch of Isthmic, which used to be spoken in Colombia and became extinct in the 18th century. Muisca had an order of possessor-possessed in attributive possession, cf. (56). Some nouns appearing in the possessor slot underwent final-vowel truncation (Ostler 1994: 208), i.e. muysca > muysc in (56), and zepaba $>$ zepab in (57). 
(56)

\begin{tabular}{|c|c|c|c|c|}
\hline $\begin{array}{l}\text { muysca } \\
\text { person }\end{array}$ & $\begin{array}{l}\text { cubun } \\
\text { language }\end{array}$ & $>$ & $\begin{array}{l}\text { muysc- } \varnothing \\
\text { person-GEN }\end{array}$ & $\begin{array}{l}\text { cubun } \\
\text { language }\end{array}$ \\
\hline
\end{tabular}

'Person's language (i.e. Muisca)' (sтм: 208)

Possessive predications were built with a copula following the possessed (57).

(57)

$\begin{array}{llll}z e-p a b-\varnothing & \text { ipqua } & \text { gue } & \text { MUISCA } \\ \text { my-father-GEN } & \text { something } & \text { is }\end{array}$

'It is something of my father.' (lit: 'my father's something is.') (sTM: 208)

The form <Ipqua>, which I will argue is the source for the possessor markers in languages of the Isthmic branch, appears in other manuscripts as <ipcua> (González de Pérez 1980: 96). ${ }^{23}$ According to Constenla (1981: 146), the graphemes $<\mathrm{c}>$ and $<$ qu $>$ in Muisca represent [k]. In general, $<\mathrm{c}>$ was used before $<\mathrm{a}>,<\mathrm{o}>$ and $<\mathrm{u}>$, while $<\mathrm{qu}>$ before $<\mathrm{i}>$ and $<\mathrm{e}>$. Because of the existence of $<$ ipcua $>$ in other Muisca manuscripts, it is safe to assume that the phonetic realization of this word was most likely [ipkua] or [ipkwa]. ${ }^{24}$

A similar change is observed in the available literature on grammaticalization. Heine \& Kuteva (2002: 296) offer examples from several languages in which (presumably) a noun meaning 'thing' is the source of a genitive marker (or, as the authors call it, a marker of attributive possession, something akin to the English 'of'). Languages for which this change is attested include Thai, Khmer, Japanese and Kxoe. Heine \& Kuteva state that more research is needed to understand the nature and genetic/aeral distribution of this grammaticalization pattern. Relevant to the present discussion, the grammaticalization of

23 Two external reviewers have noticed that this Muisca form might be bi-morphemic. This observation is supported by two facts. First, if it were to be further analyzed, the most likely syllable division would be i-pcua (Nicholas Ostler, p.c.) given that pcua is an extremely common syllable in Muisca (e.g. pcua 'tongue, marrow, pip' and pcuapcua 'hat' (Adam 1878: 100)). Second, the initial vowel of $i$-pcua seems to be subject to phonological change (cf. орсиа, ерсиа, ирсиа (González de Pérez 1980: 96). I do not currently have an etymology for the possibly bi-morphemic form i-pcua.

24 In other sources, such as the prescriptive grammar of Lugo (1619) and López García Molins (1995), ipqua is said to be a 'genitive case marker'. However, Nicholas Ostler (p.c.) informs me that this is a misunderstanding, possibly due to the wish of the Catholic friar Bernardo de Lugo to find in Muisca the same categories of Latin, such as the genitive case. The word ipqua is the Muisca equivalent of the interrogative pronoun 'what'. When it has this function, it must be followed by an interrogative particle ( $u a$ or $o$ as in ipqua $u a$ or ipquo). This interrogative pronoun can also be used after a noun in the genitive (i.e. a noun which sometimes undergoes final-vowel truncation), and in that case it means 'something' (i.e. X's something > X's property). 
'something' > possessor marker (> ergative marker) in Chibchan relies on similar attested cases. $^{25}$

Appendix A offers a historical reconstruction of a possible proto-form from which Muisca ipcua, Guaymí gwe, Bribri and Cabécar wã could have originated. The reconstruction is based on the comparative Chibchan phonology of Constenla (1981), as updated in later publications (Constenla 1989, 2008). As readers will notice, the reconstruction based on the comparative method in Appendix A is far from perfect. The actual synchronic form in a given language cannot always be predicted by regular sound change and in many instances, idiosyncratic sound changes need to be posited. However, there is additional evidence in favor of an ancient possessor subject marker in other languages of the family.

Several other languages within the Chibchan family seem to have retained fragments of the proto-form *i-pkwə. In Boruca (Western Isthmic), when the possessor within a possessive NP is a proper name, a personification or an animal, it can be marked by $i$ or ígui (Castro 2008: 67), as in (58).

$\begin{array}{lll}\text { (58) Juan ígui ú } & \text { BORUCA } \\ \text { J. PSSR house } & \\ \text { 'Juan's house' (BT: } 68) & \end{array}$

The form <ígui> (phonetically [ígi]) is a variation of <égui> which results from the blend of two segments: $\langle e ́ c\rangle$, a postposition which indicates possession, plus the pronominal segment $<i>$ (Miguel Angel Quesada Pacheco, p.c.). Although this remains simply a speculation, it could be that Boruca éc $\sim i c$ is an eroded reflex of *ipkwə. Since ${ }^{*} \mathrm{i}>\mathrm{i}$ in Boruca (Constenla 1981: 199) and *p > $\varnothing$ before ${ }^{*} \mathrm{k}$ (Constenla 1981: 220), regular sound change would give /ik/ $(<\mathrm{ic}>$ ) as a result. The loss of the rest of the proto-form would then be idiosyncratic. ${ }^{26}$

Other Chibchan languages form their 'have' verb by combining the verb 'be' with a prefix that has the form of $k w$ - or $k$ - plus some sort of vowel. This is the case of Rama, a Chibchan language from Nicaragua. In Rama, the verb 'have' is formed by the verb aakar 'be' plus the prefix kw- (Stassen 20o9: 632). This

\footnotetext{
25 Doris L. Payne has suggested to me that ipcua 'something' might be a possessive classifier rather than a generic noun meaning 'something'. Unfortunately, this question remains open, given the limited data available on Muisca.

26 Given the scenario outlined so far in terms of Proto-Chibchan cognates of *i-pkwə, the $\tilde{\imath}$ marker, found in Teribe in the construction in which the possessor follows the possessed and is marked by $\tilde{\imath}$ (see Table 6.2), might also be a heavily eroded reflex of *i-pkwə. I do not currently have, however, an explanation for the nasality of the vowel $/ \mathrm{i} /$, which is not predicted by regular sound change. Therefore, this remains only a speculation.
} 
prefix is not used elsewhere as a postposition or a pre-verb in the language and synchronically the verb 'to have' should be considered monomorphemic (Craig p.c. in Stassen 2009). Rama has relational preverbs synchronically and diachronically derived from postpositions (Craig \& Hale 1988: 313) which become prefixed to verbs by some sort of incorporation process, yielding a construction similar to an applicative. As such, cognates to etymological (and synchronic) postpositions can sometimes be found as prefixes on verbs. An example of alienable possessive predication with the verb 'have' in Rama is offered in (59).

ngainguk hap i-kwaakar
money some 3 SG-have
'He has some money.' (Craig 1990: 61)

Damana, a Chibchan language from Colombia, displays a similar pattern (Stassen 2009: 632). The verb 'have' is kuntu, formed by nun 'be' plus the dative or benefactive $k u$, phonetically [kə] (Trillos Amaya et al. 1989: 47). This tendency is also found in Paya, the northernmost Chibchan language from Honduras: the existential šu combines with the benefactive prefix $k \grave{a}$ - to obtain the verb 'have' (Holt 1999: 77). In the light of what has been noted about relational preverbs, the hypothesis is that the proto-form *i-pkwə yields $k w$ - in Rama, $k t$ - in Damana, and $k \dot{a}$ - in Paya. ${ }^{27}$ These erstwhile preverbal postpositions could then have become prefixed to the verb. In all cases, there would be extreme phonological erosion, presumably idiosyncratic, consistent with grammaticalization or lexicalization.

For the sake of completeness, I should mention that an anonymous reviewer proposed that gue 'be' in (57) may be the source of the Possessor markers wã in Bribri and Cabécar and gwe in Guaymí. According to this hypothesis, we would need to posit the existence, in the proto-language, of a construction such as *[Possessed- $\varnothing$ Possessor $-\varnothing]={ }^{*}$ gue which was then reanalyzed as *[Possessed- $\varnothing]$ [Possessor-*gue]. In this reanalysis, a clause final existential particle is reanalyzed as a possessive particle syntactically attached to the Possessor NP. After the reanalysis, a change in the order of the two NPs would be posited, where the Possessor NP marked by *gue would come before

27 Reflexes of the consonant portion of the Rama, Damana and Paya prefixes appear to be regular. In Paya, ${ }^{*} \mathrm{k}>\varnothing$ word-initially and ${ }^{*} \mathrm{k}>\mathrm{k}$ elsewhere (Constenla 1981: 250 ). In Rama, ${ }^{*} \mathrm{k}>\mathrm{k}$ (Constenla 1981: 257). In Damana, ${ }^{*} \mathrm{k}>\mathrm{g}$ intervocalically and ${ }^{*} \mathrm{k}>\mathrm{k}$ elsewhere (Constenla 1981: 313). Reflexes of the vowel portion of these prefixes do not appear to be regular in the case of Paya and Damana. 
the Possessed NP, possibly for topicality reasons. In support of this analysis, Heine \& Kuteva (2002: 127) present several languages in which an existential verb has grammaticalized into a possession marker in possessive predications. According to Heine \& Kuteva this type of reanalysis requires the possessee NP to be the subject and the possessor NP to be a genitival modifier of the subject. I propose one main counterargument to this hypothesis. The exact phonetic value of $<$ gue $>$ in Muisca is uncertain, due to Spanish orthographic issues at the time in which Spanish Catholic friars transcribed Muisca (see Constenla 1981: 147). There are at least six possible phonetic values for Muisca $\langle$ gue $>$ : [gwe], [we], [ge], [gwi], [wi] and [gi] (Nicholas Ostler, p.c.). This uncertainty creates problems in the reconstruction of a possible proto-form (see Appendix B). In general, the reconstruction presented in Appendix B seems to pose slightly more complications than the reconstruction for my hypothesis (cf. Appendix A). By no means is this second hypothesis untenable, but as presented above, the first hypothesis seems to have more supporting evidence.

Based on the evidence advanced so far, rather than a shallow innovation restricted to the Viceitic group within the Isthmic Branch, it is now necessary to reconstruct a proto-form, and then to posit retention in Guaymí, Bribri and Cabécar, along with possible relics in other languages (Boruca, Rama, Damana, Paya). The complete loss of this proto-form in the other languages would not be entirely unexpected: there would have been a time lapse of centuries for this morpheme to be lost across the other languages (something that cannot be stated for the 'innovation' hypothesis).

However, the conservatism hypothesis sets forth a question. This question has to do with the marking of attributive possession versus possessive predication and with how a possessor marker gained subject properties in some of the languages involved in the comparison. In particular, in the Viceitic subgroup, alienable and inalienable attributive possession do not display any kind of marking on the (NP-internal) possessor, cf. (11) and (12). In possessive predications however, we find that the possessor subject is marked by $w \tilde{a}$, which presumably comes from a proto-form meaning 'something' in Proto-Chibchan. Most importantly, the possessor NP marked by wã in possessive predications displays subject properties. For instance, in attributive possession in Bribri, the possessor and the possessed form an indivisible constituent (i.e. in a possessive NP), independently of whether the possession is alienable or inalienable. Thus, compare (6o) and (61).

(6o) Alí chíchi sế-r-ke tër kềkra-ë BRIBRI
A. $\operatorname{dog}$
live-MVC-IPFVII
exist.POS.SG
always-INT

'Alís dog is always lying down.' (EL) 


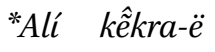
chíchi sé́-r-ke
$t \ddot{e r}$
BRIBRI
A. always-INT dog live-MVC-IPFVII exist.POs.sG
*'Ali's dog is always lying down.' (EL)

However, the possessor subject marked by wã and the possessed object in possessive predications do not form a constituent. The same adverb that cannot go between possessor and possessed in (61) can separate them in (62).
Alí wã kê̂ेkra-ë
$n \hat{\tilde{u}} k \ddot{o l} \quad$ tso'
A. PSSR always-INT money exist
'Alí always has money.' (EL)

In Guaymí, a possessive predication looks identical to attributive possession because there is no overtly expressed verb. Unlike the Viceitic languages, the possessor is marked by gwe in both attributive possession and possessive predications (Quesada Pacheco 2008: 72). The only data I have been able to find which tells something about constituency in a possessive predication is from Young \& Givón (1990: 211), when the sentential negation occurs between the possessed and the marked possessor.
(63) krägä nyaka nun-gwe
medicine NEG 1PL-GEN
'We have no medicine.' (lit: 'Medicine is not ours.')

GUAYMÍ

One example is far from sufficient to draw conclusions about constituency in Guaymí: synchronic data is needed to determine whether attributive possession and possessive predication are really identical in this language in all aspects, including, for example, intonation, and whether the Possessor and the Possessed form a constituent in either or both attributive possession and/or possessive predication.

Whatever the case might be, in Bribri and Cabécar, attributive possession lacks marking on the possessor, while possessive predications feature a special marker for the possessor subject. In this respect, Stassen (2009:27) states that the ways of marking possession on NPs and in clauses do not seem to abide by any predictable match: there are languages in which attributive possession derives from possessive predication (clauses) and languages in which it does not. In the latter case, attributive possession and possessive predication display divergent morphosyntactic patterns:

It is theoretically possible that, in some languages, a distinction is made between the clausal and the phrasal syntax of possession. In particular, 
it is possible that the phrasal syntax of possession is more grammaticalized than the clausal syntax of possession is. In such languages, the possessor NP and the possessee NP may form a constituent in attributive possession, while they do not form a constituent in predicative possession. (Stassen 2009: 114)

This theoretical possibility is the case in Bribri: the possessor and the possessed form a constituent in attributive possession but not in possessive predication.

Within the Viceitic group, the question is then how the inherited protoform ended up only in possessive predications and when and how the inherited proto-form, reanalyzed as a possessor, developed subject properties outside of a possessive NP.

This section has reached the conclusion that the conservatism hypothesis wins over the innovation hypothesis: the languages which synchronically have a possessor marker in alienable possessive predications have inherited and reanalyzed it possibly from a proto-form which originally meant 'something', or 'thing' or 'property'.

Future research should address whether other Isthmic languages might have preserved relics of the proto-marker *i-pkwə in inalienable possessive predications. As a preview, in Bribri, inalienable possession can be expressed by constructions which feature the copula dör or the existential tã . The inalienable possessor is usually not marked by the postposition wã. However, in the domain of objects of personal use, the possessor can be optionally marked by $w \tilde{a}$, at least in the case of certain objects, such as 'house' in (64).
(64) $i e^{\prime} \quad(w \tilde{a}) \quad u ́ \quad t \tilde{a}^{\prime}$
ISG PSSR house exist
'I have a house.' (i.e. I do not rent this house, rather I live in it) ${ }^{28}$ (EL)

In Cabécar, on the other hand, the inalienable possessor must be marked by the postposition wã. Unlike Bribri, the existential tsố can be used, cf. (65), along with $t \tilde{a}$, cf. (66), to express inalienable possession.
(65) yís wã kuta tsố tkếl CABÉCAR
1SG PSSR sister exist four
'I have four sisters.' (DCE: 310)

\footnotetext{
28 A similar example, in which wã is not indicated as optional, is found in Dickeman-Datz (1984: 119).
} 


$\begin{array}{lllll}\text { (66) mõgú } & \text { wã } & \text { wöbla shabóo } & \text { tã CABÉCAR } \\ \text { owl } & \text { PSsR eyes almost.full exist } & \\ \text { 'Owls have really big eyes.' (DCE: } 271)\end{array}$

As far as the Viceitic languages are concerned, Cabécar appears to be the more conservative in that (i) it has preserved the possessor marker wã in both types of possessive predication; and (ii) there is no distinction in the verbs used to express alienable and inalienable possession.

\section{5}

\section{Conclusions}

This article has demonstrated how the syncretism between the ergative marker and the possessor subject marker in the Viceitic languages of the Chibchan family came to be. Further, the article has posited a possible origin for this morpheme, wã, in Proto-Chibchan *i-pkwə 'something'. Although several questions still remain unanswered, digging into diachrony has proved pivotal to understanding why Bribri and Cabécar display the relatively uncommon phenomenon of differential ergative marking.

In $\S 3$ (and subsections therein), I demonstrated that the possessor marker $w \tilde{a}$ was reanalyzed as an ergative marker in Bribri and Cabécar: this was possible because the perfect construction in which $w \tilde{a}$ is found historically came from a possessive predication, a well-established evolutionary pattern. The discovery of this path of reanalysis brought about inquiries with respect to the ultimate origin of this marker, as well as a methodological dilemma concerning the choice between innovation and conservatism. Comparative work has shown that this marker is not found in more closely related languages within the larger branch: a reasonable assumption was then to claim that it represents an innovation within a sub-group or two of the larger branch. This assumption, in turn, made room for a potential contradiction: if the innovation hypothesis were right, then there should be a readily available synchronic source for $w \tilde{a}$, whether in the languages that have it or in more closely related ones. The absence of such a synchronic source proved fundamental to giving more credit to the hypothesis that the morpheme is a conservative relic.

This possibility led to further inquiries outside of the immediate larger branch of which the languages under survey were part, into more distant branches (cf. §4). The identification of a cognate form in Muisca, a language as far away as Colombia, invited the reconstruction of a proto-form meaning 'thing', 'something' or 'property' in Proto-Chibchan which would have been 
reanalyzed in several Chibchan languages as a possessor marker, and in three of these, further as an ergative marker. This reanalysis is supported by attested changes in the same direction ('thing' > possessor marker). The reconstruction of this form was supported by the presence of cognate forms scattered throughout the Chibchan family which abide (mostly) by regular sound change rules in their reflexes of the proto-form (see Appendix A). Additional evidence was found in other Chibchan languages which could have incorporated a heavily eroded relic of the proto-form at the beginning of certain verbs (i.e. the grammaticalization of preverbal postpositions into verbal prefixes).

In addition, because the ergative marker $w \tilde{a}$ came from a possessor (i.e. from an 'oblique' case), the presence of 'Type B' ergativity has been determined to exist within the Chibchan family, at least in Bribri, Cabécar and Guaymí. Given that this type of ergativity arises from the reanalysis of an oblique case marker (such as a possessor), one future inquiry should be concerned with whether the standard Proto-Chibchan ergative marker * $\mathrm{tV}$ is an instance of 'Type A' ergativity, that is, of a passive made obligatory, or of something else.

Although we now know the source of the ergative marker wã in perfect constructions, this marker is also found in several other constructions in both languages, such as the transitive perfective negative and the caused motion construction, among others. Future studies will need to probe the spread of this innovative ergative marker into these other constructions. ${ }^{29}$

\section{Appendix A: Reconstruction of the Proto-Form *i-pkwə and Its Reflexes in Different Chibchan Languages}

The hypothesis illustrated in this appendix is that the forms presented in Table 6.3 represent a cognate set of reflexes of the Proto-Chibchan form *i-pkwa '(some)thing'.

Two observations are in order before presenting the regular (and irregular) sound changes which operated to give the reflexes of the proto-form ${ }^{*} i$-pkwə in each of the languages in Table 6.3. First, when comparing and reconstructing Chibchan languages,

29 Many unsolved questions remain with respect to ergative marking in the Viceitic languages of the Chibchan family. For instance, it is unclear at the present time why the innovative ergative marker wã appears in negative domains in Cabécar and Bribri, although in the latter to a lesser extent. An anonymous reviewer interestingly suggested that the presence of wã in negative contexts indicates some sort of pragmatic force associated with this ergative marker, possibly connected to the existential sense presumably present in the original construction. 
TABLE 6.3 Potential cognates for a proto-form *i-pkwə in some Chibchan languages

\section{Proto-form 'thing'/'something'}

\section{*i-pkwə}

MUISCA

CABÉCAR

BRIBRI

GUAYMÍ [i-pkwa] (<ipkua, ipcua $>)$

[wã] $(<w a ̃>)$

[wã] $(<w a ̃>)$

[gwe/kwe] (<gwe/kwe g $\left.^{\mathrm{a}}\right)$

a Gwe is found in the variety of Guaymí spoken in Costa Rica. Kwe occurs in the variety spoken in Panama, of which the Costa Rican variety is considered a dialect (Murillo 2010).

it is often the case that a given root appears with different vowel endings (Constenla 1989, 2008) in different languages. These vowel endings are akin to 'thematic vowels' and have no function other than combining with a given root. ${ }^{30}$ Constenla (2008: 130) offers several examples of this phenomenon and acknowledges that it can be a serious problem when reconstructing within Chibchan. For instance, for the meaning 'salt, sea', there are reflexes of the proto-root *dahg plus: (i) the vowel ending /*-e/ in three Chibchan languages from Central America (Paya /tá:ké/, Bribri /dadłîl/, Cabécar / $\operatorname{dad} \hat{\mathbf{I}} /$ ); (ii) the vowel ending $/{ }^{*}$-u/ in three Chibchan languages from Colombia (Cogui /nəkku/, Damana /ningu/, Ika /nəggi); and (iii) a sequence of the vowel endings /*-u/ and /*-a/ in two other Chibchan languages from Colombia (Muisca /nigua/, Tunebo / rauwa/). Different vowel endings are also common language-internally (for example, in Cuna /nue/, /nui/ and /nua/ all mean 'good'). In the reconstructions I propose here final vowels often do not form a regular correspondence set, but this is just one specific instance of a more general phenomenon in the family.

Second, for this historical reconstruction I rely entirely on the comparative Chibchan phonology of Constenla (1981). The vowel system reconstructed in $1981 \mathrm{com}-$ prised 8 vowels $\left(/{ }^{*} \mathrm{i} /,\left.\right|^{*} \mathrm{I} /, /^{*} \mathrm{e} /, /{ }^{*} \mathrm{a} /,\left.\right|^{*} \mathrm{\partial} /,\left.\right|^{*} \mathrm{o} /,\left.\right|^{*} \mathrm{v} /\right.$, and $\left./{ }^{*} \mathrm{u} /\right)$. This system was subsequently amended (Constenla 1989, 2008) and reduced to 5 vowels $\left(/ *^{*} \mathrm{i} /,{ }^{*} \mathrm{e} /, /{ }^{*} \mathrm{a} /, /{ }^{*} \mathrm{o} /\right.$, $/{ }^{*} \mathrm{u} /$ ). The proto-phonemes $/{ }^{*} \mathrm{I} /, /^{*} \mathrm{v} /$ and $/{ }^{*} \mathrm{\partial} /$ proposed in 1981 were later ascribed to $/ * \mathrm{i} /,\left.\right|^{*} \mathrm{u} /$ and $/{ }^{*} \mathrm{a} /$ respectively. For the purposes of this reconstruction, then, the protoform *i-pkwə would be ascribed to *i-pkwa.

30 This is my translation of 'formativos vocálicos' in Constenla $(1989,2008)$. In fact these endings include more than just vowels. Constenla (2008: 130) enumerates at least the fol-

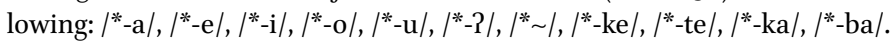


In each of the following tables, the first column shows the proposed proto-form, the second column illustrates the reflexes of each phoneme of the proto-form *i-pkwə in a given daughter language and the regular sound changes, as described in the comparative Chibchan phonology of Constenla (1981). Page numbers in parentheses refer exclusively to this source. The third column indicates the kind of sound change which took place. Sound changes which are language specific and cannot be reconstructed by claiming regular sound change are indicated in parentheses as idiosyncratic. The fourth column summarizes all the stages of the evolution from the proto-form to the modern reflex. A remark which applies to all tables is that Proto-Chibchan probably had asyllabic allophones of $/ \mathrm{i} /$ and $/ \mathrm{u} /$ at the beginning of syllables when these protovowels were followed by another vowel (Constenla 1981: 208). This is why, in all tables in Appendix A (and B), / $\mathrm{u}$ / followed by another vowel has been transcribed as [w].

As can be seen in Table 6.4, the reflex of $/{ }^{*} \mathrm{i}$-pkwə/ in Muisca is conservative with respect to other languages and abides by regular sound change. As can be seen in Table 6.5, in Cabécar, if we assume that the proto-form was bi-morphemic and that the initial *i- was lost, we are left with the form *kwã > *wã. This kind of simplification $(/ \mathrm{kw} />/ \mathrm{w} /)$ is attested as a tendency in the languages of South and Central America (Holmer 1947: 56). For Bribri, the same reflexes presented for Cabécar apply, with the exception that Constenla (1981: 194) indicates that /*ə/ has /à/ as a reflex (with a low tone) in Bribri. Conceivably, because of centuries of intimate contact with Cabécar, an intermediate form /wà/ could have become nasalized; alternatively, the nasalization originated independently as a compensatory strategy for the erosion of /i-kwà/. As for the phonological erosion that has been posited as an idiosyncratic sound change in Bribri and Cabécar, this sort of reduction is widely attested in cases of

TABLE 6.4 Reflexes of the proto-form *i-pkwə in Muisca

\section{Muisca}

\section{Protoform Regular sound changes yielding Type of sound change Evolution /*i-pkwə/ reflexes}

\begin{tabular}{|c|c|c|}
\hline $\begin{array}{l}/{ }^{*} \mathrm{i} />/ \mathrm{i} / \text { in non-final position } \\
(\mathrm{p} .199)\end{array}$ & - & /i-pkwə/ \\
\hline$/{ }^{*} \mathrm{p} />/ \mathrm{p} /$ before $/{ }^{*} \mathrm{k} /(\mathrm{p} .220)$ & - & /i-pkwə/ \\
\hline$/{ }^{*} \mathrm{k} />/ \mathrm{k} /(\mathrm{p} .228)$ & - & /i-pkwə/ \\
\hline $\begin{array}{l}/{ }^{*} \mathrm{u} />/ \mathrm{u} / \text { in non-final position } \\
(\mathrm{p} .204)\end{array}$ & - & /i-pkwə/ \\
\hline$/{ }^{*} \mathrm{\partial} />/ \mathrm{a} /$ after $/{ }^{*} \mathrm{u} /(\mathrm{p} .195)$ & vowel lowering & /i-pkwa/ \\
\hline
\end{tabular}


TABLE 6.5 Reflexes of the proto-form *i-pkwə in Proto-Viceitic

\section{Proto-Viceitic}

Protoform Regular sound changes

Type of sound change Evolution

/*i-pkwə/ yielding reflexes

\begin{tabular}{|c|c|c|c|}
\hline & $/{ }^{*} \mathrm{i} />/ \mathrm{i} /($ p.199) & - & /i-pkwə/ \\
\hline & $\begin{array}{l}/{ }^{*} \mathrm{p} />\mid \varnothing / \text { before } /{ }^{*} \mathrm{k} / \\
(\mathrm{p} .219)\end{array}$ & cluster reduction & /i-kwə/ \\
\hline & $/{ }^{*} \mathrm{k} />/ \mathrm{k} /(\mathrm{p} .227)$ & - & /i-kwə/ \\
\hline & $/{ }^{*} \mathrm{u} />/ \mathrm{u} /(\mathrm{p} .203)$ & - & /i-kwə/ \\
\hline Cabécar & /*ə/>/à/ or /ã/ (p.194) & $\begin{array}{c}\text { vowel lowering, low tone } \\
\text { or nasalization }\end{array}$ & /i-kwã/ \\
\hline & - & $\begin{array}{c}\text { phonological erosion } \\
\text { (idiosyncratic) }\end{array}$ & /wã/ \\
\hline Bribri & /*ə/>/à/ (p.194) & vowel lowering, low tone & /i-kwà/ \\
\hline & - & $\begin{array}{c}\text { phonological erosion } \\
\text { (idiosyncratic) }\end{array}$ & /wà/ \\
\hline & - & $\begin{array}{c}\text { nasalization due to } \\
\text { contact or loss of segment } \\
\text { (idiosyncratic) }\end{array}$ & /wã/ \\
\hline
\end{tabular}

grammaticalization (Lehmann 1985; Traugott \& Heine 1991; Heine et al. 1991; Hopper \& Traugott 1993; Bybee et al. 1994; Heine \& Kuteva 2007; inter alia) - wã is a highly grammatical morpheme and, as such, because of frequency of use, it is reasonable to assume that erosion happens at a higher rate compared to lexical morphemes.

In the case of Guaymí (see Table 6.6), the idiosyncratic change of vowel raising is supported by the description of Quesada Pacheco (2008: 26), who shows that vowel harmony in the form of raising is common in this language. Here, we would have to posit that vowel harmony occurred before the loss of the initial *i- or, alternatively, we would have to reconstruct a different vowel ending for Guaymí based on the attested tendency of Chibchan languages to show different vowel endings for the same root (Constenla 1989, 2008). Therefore, Guaymí gwe/kwe could be the result of the bimorphemic root *i-pkw- plus the vowel ending *-e which gave /e/ as a reflex in Guaymí (Constenla 1981: 278). 
TABLE 6.6 Reflexes of the proto-form *i-pkwə in Guaymí

\section{Guaymí}

\begin{tabular}{|c|c|c|c|}
\hline $\begin{array}{l}\text { Protoform } \\
* / \text { i-pkwə/ }\end{array}$ & $\begin{array}{l}\text { Regular sound changes } \\
\text { yielding reflexes }\end{array}$ & Type of sound change & Evolution \\
\hline & $/ * \mathrm{i} />/ \mathrm{i} / \mathrm{a}(\mathrm{p} .279)$ & - & /i-pkwə/ \\
\hline & $/ * \mathrm{p} />\mid \varnothing /$ before $/{ }^{*} \mathrm{k} /(\mathrm{p} .284)$ & cluster reduction & /i-kwə/ \\
\hline & $/{ }^{*} \mathrm{k} />/ \mathrm{k} /(\mathrm{p} .284)$ & - & /i-kwə/ \\
\hline & $/{ }^{*} \mathrm{u} />/ \mathrm{u} /(\mathrm{p} .28 \mathrm{o})$ & - & /i-kwə/ \\
\hline & $\mid{ }^{*} \mathrm{\partial} />/ \mathrm{a} /$ after $/{ }^{*} \mathrm{u} /(\mathrm{p} .277)^{\mathrm{b}}$ & - & /i-kwa/ \\
\hline & - & $\begin{array}{l}\text { vowel harmony and } \\
\text { raising (idiosyncratic) }\end{array}$ & /i-kwe/ \\
\hline & - & $\begin{array}{c}\text { loss of initial vowel } \\
\text { (idiosyncratic) }\end{array}$ & /kwe/ /gwe/ \\
\hline
\end{tabular}

a The reflex /i/ in Guaymí occurs in the general 'elsewhere' environment. /*i/gave /e/ as a reflex after a bilabial and /I/ before $/ * 2 /$ or $/{ }^{*} \mathrm{k} /$ if not preceded by a voiced consonant (Constenla 1981: 279).

b Constenla (1981: 278) states that in one postposition /*a/ gave /e/ and in other two postpositions either $/ *^{*}$ / or /*a/ gave /e/. He hypothesizes that the phonological environment could be in word final position if unstressed. However, in these three cases, /e/ is never preceded by $/{ }^{*} \mathrm{u} /$.

\section{Appendix B: Reconstruction of the Proto-Form *kwə *kwe 'exist' and Its Reflexes in Different Chibchan Languages}

The hypothesis illustrated in this appendix is that the forms presented in Table 6.7 represent a cognate set of reflexes of the Proto-Chibchan form "kwə *kwe 'exist'.

The great variation in vowel endings for certain roots across Chibchan languages (see Appendix A) represents the same problem for this reconstruction (see below). Two additional observations are relevant for the reconstruction in Appendix B. First, I have added to the cognate set, the Cuna form $<k u e>$, an independent verb with the meaning of 'be, take place' (Holmer 1947: 156). Although in Cuna the hypothesized reanalysis of *kwə ${ }^{*}$ kwe into a possessive particle has not taken place, the form is similar enough to the others in meaning and shape for it to be considered as a possible cognate. Second, the phonetic realizations of $<$ gue $>$ in Muisca vary greatly, and it is impossible to determine exactly which one of the six possibilities is the correct reflex for 
TABLE 6.7 Potential cognates for a proto-form *kwə ${ }^{*}$ kwe in some Chibchan languages

\section{Proto-Form 'exist, be'}

${ }^{*}$ kwə $\sim{ }^{*}$ kwe

Muisca

Cabécar

Bribri

Guaymi

Cuna [gwe], [we], [ge], [gwi], [wi] , [gì] $\left(<\right.$ gue, guy $\left.{ }^{\mathrm{a}}>\right)$

$$
[w a ̃](<w a ̃>)
$$$$
\text { [wã] }(<w a ̃>)
$$

[gwe/kwe] $(<$ gwe $/$ kwe $>)$

$[\mathrm{kwe}]^{\mathrm{b}}(<\mathrm{kue}>)$

a A symbol similar to $<\gamma>$ is found in the Lugo grammar of Muisca (1619) and it is considered to represent a vowel intermediate between $[\mathrm{e}]$ and [i], probably [i].

b Often realized phonetically as [ywe] or [we].

constructing the correspondence (see discussion in $\S 4$ ). For reasons of convenience, I have based the reconstructions in this Appendix on the assumption that Muisca $<$ gue $>$ is phonetically [gwe]; this choice has no consequences for assessing the plausibility of the reconstruction.

As in Appendix A, in each of the following tables, the first column shows the proposed proto-form, the second column illustrates the reflexes of each phoneme of the proto-form *kwə ${ }^{*}$ kwe in a given daughter language and the sound changes which took place according to regular sound change, as described in the comparative Chibchan phonology of Constenla (1981). Page numbers in parentheses refer exclusively to this source. The third column indicates the kind of sound change which took place. Sound changes which are language specific and cannot be reconstructed by claiming regular sound change are indicated in parentheses as idiosyncratic. The fourth column summarizes all the stages of the evolution from the proto-form to the modern reflex. As a final remark, although most forms in Table 6.7 present an initial /g/ instead of $/ \mathrm{k} /$, the reconstruction of a $\mathrm{g}$ posits serious problems in terms of reflexes. ${ }^{31}$ Therefore, * $k$ has been preferred.

In the scenario outlined by the reconstruction in Appendix B, Muisca (see Table 6.8 ) is the most problematic case. The main problem is that for all the proto-vowels that could reasonably be posited for the proto-form (i.e. *a, *e, *ə) Muisca has /a/ as a reflex (Constenla 1981: 192 ff.). Positing a Muisca form without /u/, such as [ge] or [gi],

31 Based on Constenla (1981), reconstructing a * $\mathrm{g}$ for the forms in Table 6.7 would give the following non-expected reflexes: /h/ in Cabécar, / $\mathrm{y} /$ in Guaymí and /s/ in Cuna. 
TABLE 6.8 Reflexes of the proto-form *kwə *kwe in Muisca

\section{Muisca}

Protoform Regular sound changes yielding Type of sound change Evolution /*kwə/ reflexes

$\begin{array}{lcc}/{ }^{*} \mathrm{k} />/ \mathrm{k} /(\mathrm{p} .228) & - & / \mathrm{kwə} / \\ /{ }^{*} \mathrm{u} />/ \mathrm{u} / \text { in non-final position } & - & / \mathrm{kwə} / \\ (\mathrm{p} .2 \mathrm{O} \text { ) } & & \\ /{ }^{*} \mathrm{\partial} />/ \mathrm{a} / \text { after } /{ }^{*} \mathrm{u} /(\mathrm{p} .195) & - & / \mathrm{kwa} / \\ - & \text { vowel raising } & / \mathrm{kwe} / \\ & \text { (idiosyncratic) } & \\ & \text { voicing } & / \mathrm{gwe} / \\ & \text { (idiosyncratic) } & \end{array}$

\section{Cabécar}

Protoform Regular sound changes yielding Type of sound change Evolution /*kwə/ reflexes

\begin{tabular}{|c|c|c|c|}
\hline & $/{ }^{*} \mathrm{k} />/ \mathrm{k} /(\mathrm{p} .227)$ & - & /kwə/ \\
\hline & $/{ }^{*} \mathrm{u} />/ \mathrm{u} /(\mathrm{p} .2 \mathrm{O} 3)$ & - & /kwə/ \\
\hline \multirow[t]{3}{*}{ Cabécar } & /*ə/>/à/ or /ã/ (p.194) & vowel lowering, low & /kwã/ \\
\hline & & tone or nasalization & \\
\hline & - & $\begin{array}{l}\text { phonological erosion } \\
\text { (idiosyncratic) }\end{array}$ & /wã/ \\
\hline \multirow[t]{3}{*}{ Bribri } & |*əo/>/à/ (p.194) & vowel lowering & /kwà/ \\
\hline & - & $\begin{array}{l}\text { phonological erosion } \\
\text { (idiosyncratic) }\end{array}$ & /wà/ \\
\hline & - & $\begin{array}{c}\text { nasalization due to } \\
\text { contact or loss of } \\
\text { segment (idiosyncratic) }\end{array}$ & /wã/ \\
\hline
\end{tabular}


is not of much help, because the loss of asyllabic / $\mathrm{u} /$ would also need to be posited as an idiosyncratic sound change.

The same observations made in Appendix A for Bribri also apply to this reconstruction. The intermediate form /wà/ in Table 6.9 could have become nasalized due to contact with Cabécar, or the nasalization could have originated independently, as a compensatory strategy for the loss of $/ \mathrm{k} /$ (erosion).

In the case of Guaymí and Cuna (see Tables 6.10 and 6.11 respectively), an alternative solution to the idiosyncratic vowel raising would be to posit the presence of two proto-forms with an alternation in the final vowel portion: *kw-ə (> *kwa in the revised comparative phonology of Constenla 1989 and 2008 in which *ə is ascribed to *a) for Muisca, Cabécar and Bribri, and *kw-e for Guaymí and Cuna. In both of these

TABLE 6.10 Reflexes of the proto-form *kwə *kwe in Guaymí

\section{Guaymí}

\begin{tabular}{clcc}
$\begin{array}{c}\text { Protoform } \\
* / \text { kwə/ } \\
\text { or } / \text { kwe } /\end{array}$ & $\begin{array}{l}\text { Regular sound changes } \\
\text { yielding reflexes }\end{array}$ & Type of sound change & Evolution \\
\hline & & & \\
& $/{ }^{*} \mathrm{k} />/ \mathrm{k} /(\mathrm{p} .284)$ & - & $/ \mathrm{kwə} /$ \\
& $/{ }^{*} \mathrm{u} />/ \mathrm{u} /(\mathrm{p} .28 \mathrm{o})$ & $/ \mathrm{kwə} /$ \\
& $/{ }^{*} \mathrm{\partial} />/ \mathrm{a} / \mathrm{after} /{ }^{*} \mathrm{u} /(\mathrm{p} .277)^{\mathrm{a}}$ & - & $/ \mathrm{kwa} /$ \\
& - & vowel raising (idiosyncratic) & $/ \mathrm{kwe} /$
\end{tabular}

a See fn. 33 in Appendix A.

TABLE 6.11 Reflexes of the proto-form *kwə *kwe in Cuna

Cuna

\begin{tabular}{clcc}
$\begin{array}{c}\text { Protoform } \\
* / \text { kwo/ } \\
\text { or } / \text { kwe } /\end{array}$ & $\begin{array}{l}\text { Regular sound changes } \\
\text { yielding reflexes }\end{array}$ & Type of sound change & Evolution \\
\hline & & & \\
& $/{ }^{*} \mathrm{k} />/ \mathrm{k} /(\mathrm{p} .264)$ & - & $/ \mathrm{kw \partial} /$ \\
& $/{ }^{*} \mathrm{u} />/ \mathrm{u} /(\mathrm{p} .262)$ & - & $/ \mathrm{kw \partial} /$ \\
& $/{ }^{*} \mathrm{\partial} />/ \mathrm{a} /(\mathrm{p} .261)$ & - & $/ \mathrm{kwa} /$ \\
& - & vowel raising (idiosyncratic) & $/ \mathrm{kwe} /$
\end{tabular}


languages *e > e (Constenla 1981: 261, 278). This would then be a very common case of different vowel endings for a given root in different Chibchan languages (see discussion in Appendix A).

The reconstruction in Appendix $B$ has an advantage compared to that in Appendix A. Positing that the origin of wã in Bribri and Cabécar is to be found in a verbal particle could potentially explain why these languages have a verbal suffix -wã, identical in form to the possessor marker wã. However, in terms of function, the meanings of the synchronic suffix -wã include, depending on the author, "completion of an action", "movement of penetration" and "punctuality" (cf. fn. 8). These meanings do not seem, at first glance, to be derivable from a former existential particle.

Additionally, if Muisca ipqua and Boruca ic- are in fact cognates (as my reconstruction in Appendix A suggests), then the alternative reconstruction in Appendix B does not explain the presence of a prefix $i$ - not attested elsewhere and present, presumably, in at least two branches (Magdalenic and Isthmic).

\section{References}

Adam, Lucien. 1878. Etudes sur six langues américaines: dakota, chibcha, nahuatl, kechua, quiche, maya. Paris: Maisonneuve.

Arkadiev, Peter. 2017. Multiple Ergatives: From Allomorphy to Differential Agent Marking. Studies in Language 41(3): 717-780.

Benveniste, Émile. 1966. Problèmes de linguistique générale. Paris: Gallimard.

Bybee, Joan L., Revere D. Perkins \& William Pagliuca. 1994. The Evolution of Grammar: Tense, Aspect and Modality in the Languages of the World. Chicago: University of Chicago Press.

Castro, Damaris. 2008. Brunkahk Tek: An Extinct Language. Letras 43: 51-74.

Chevrier, Natacha. 2017. Analyse de la phonologie du bribri (chibcha) dans une perspective typologique: Nasalité et géminée modulée. Doctoral dissertation. Université Lumière, Lyon II.

Comrie, Bernard. 1978. Ergativity. Syntactic Typology: Studies in the Phenomenology of Language, ed. by Winfred P. Lehmann. Austin: University of Texas Press.

Constenla Umaña, Adolfo. 1981. Comparative Chibchan Phonology. Ph.D. dissertation, University of Pennsylvania.

Constenla Umaña, Adolfo. 1985. Clasificación lexicoestadística de las lenguas de la familia chibcha. Estudios de Lingüistica Chibcha 4: 155-197.

Constenla Umaña, Adolfo. 1989. Subagrupación de las lenguas chibchas: Algunos nuevos indicios comparativos y lexicoestadísticos. Estudios de Lingüística Chibcha 8: $17-72$. 
Constenla Umaña, Adolfo. 1991. Las lenguas del Área Intermedia: Introducción a su estudio areal. San José: Editorial de la Universidad de Costa Rica.

Constenla Umaña, Adolfo. 2007. La lengua de Térraba: Esbozo fonológico y gramaticaly pequeño diccionario. San José: Editorial de la Universidad de Costa Rica.

Constenla Umaña, Adolfo. 2008. Estado actual de la suclasificación de las lenguas chibchenses y de la reconstrucción fonológica y gramatical del protochibchense. Estudios de Lingüística Chibcha 27:117-135.

Constenla Umaña, Adolfo \& Enrique Margery Peña. 1979. Bribri II. San José: Editorial de la Universidad de Costa Rica.

Constenla Umaña, Adolfo \& Eugenia Ibarra Rojas. 2oog. Mapa de la distribución territorial aproximada de las lenguas indígenas habladas en Costa Rica y en sectores colindantes de Nicaragua y de Panamá en el siglo XVI. Estudios de Lingüística Chibcha 28: 109-112.

Constenla Umaña, Adolfo, Feliciano Elizondo Figueroa \& Francisco Pereira Mora. 1998. Curso básico de Bribri. San José: Editorial de la Universidad de Costa Rica.

Craig, Colette \& Ken Hale. 1988. Relational Preverbs in Some Languages of the Americas: Typological and Historical Perspectives. Language 64(2): 312-344.

Craig, Colette. 1990. Rama Kuup: Gramática Rama. Centro de Investigaciones y Documentación de la Costa Atlántica. Printed in Eugene, Oregon.

Creissels, Denis. 2013. Control and the Evolution of Possessive and Existential Constructions. Argument Structure in Flux: The Naples-Capri Papers, ed. by Elly van Gelderen, Jóhanna Barðdal \& Michela Cennamo, 461-476. Amsterdam/ Philadelphia: John Benjamins.

Creissels, Denis. 2014. Predicative Possession and Existential Predication. Paper presented at the Ecóle thématique LACITO, Méthodes en linguistique: des données empiriques aux hypothèses typologiques held in Roscoff, France, July 2014.

Dickeman Datz, Margaret. 1984. Split Ergativity and Subject in Bribri. Estudios de Lingüística Chibcha 3: 113-134.

González de Pérez, María Stella. 198o. Trayectoria de los estudios sobre la lengua chibcha o muisca. Bogotá: Instituto Caro y Cuervo.

Haig, Geoffrey. 2008. Alignment Change in Iranian Languages: A Construction Grammar Approach. New York: Mouton de Gruyter.

Heine, Bernd. 1997. Possession: Cognitive Sources, Forces, and Grammaticalization. Cambridge: Cambridge University Press.

Heine, Bernd, Ulrike Claudi \& Friederike Hünnemeyer. 1991. Grammaticalization: A Conceptual Framework. Chicago: University of Chicago Press.

Heine, Bernd \& Tania Kuteva. 2002. World Lexicon of Grammaticalization. Cambridge: Cambridge University Press.

Heine, Bernd \& Tania Kuteva. 2006. The Changing Languages of Europe. Oxford: Oxford University Press. 
Heine, Bernd \& Tania Kuteva. 2007. The Genesis of Grammar. Oxford: Oxford University Press.

Hoff, Berend J. 1995. Configurationality and Nonconfigurationality in the Carib Language of Surinam. International Journal of American Linguistics 61(4):347-377.

Holmer, Nils M. 1947. Critical and Comparative Grammar of the Cuna Language. Göteborg: Etnografiska Museet.

Holt, Dennis Graham. 1986. The Development of the Paya Sound System. Doctoral dissertation, University of California at Los Angeles.

Holt, Dennis Graham. 1999. Pech (Paya). München: LINCOM Europa.

Hopper, Paul J. \& Elizabeth Closs Traugott. 1993. Grammaticalization. Cambridge: Cambridge University Press.

Jara Murillo, Carla Victoria. 1993. I ttè: Historias Bribris. San José: Editorial de la Universidad de Costa Rica.

Jara Murillo, Carla Victoria \& Alí García Segura. 2008. Cargos tradicionales del pueblo bribri: Sĩótãmĩ / Óköm / Awá. San José: Instituto Costarricense de Electricidad.

Jara Murillo, Carla Victoria \& Alí García Segura. 20o9. Se' é yawö bribri wa: Aprendemos la lengua Bribri. San José: Unice F/Universidad de Costa Rica.

Jara Murillo, Carla Victoria \& Alí García Segura. 2013. Se’ ttö bribri ie: Hablemos en bribri. San José: E-digital $E D$.

Lehmann, Christian. 1985. Thoughts on Grammaticalization. München: Lincom Europa.

López García-Molíns, Angel. 1995. Gramática muisca. München: Lincom Europa.

Lugo, Bernardo de. 1619. Gramática en la lengva general del Nvevo Reyno, llamada mosca. Bogotá: Ediciones Sol y Luna.

Margery Peña, Enrique. 1989. Diccionario cabécar-español, español-cabécar. San José: Editorial de la Universidad de Costa Rica.

McGregor, William B. 20o9. A Typology of Ergativity. Language and Linguistics Compass $3(1): 480-508$.

Murillo Miranda, José Manuel. 2010. La oración simple ngäbére. Forma y función 23(1): 39-69.

Ostler, Nicholas. 1994. Syntactic Typology of Muisca: A Sketch. Languages in the Andes, ed. by Peter Cole, Gabriella Hermon, Mario Daniel Martin. University of Delaware: Latin American Studies.

Pache, Matthias. 2016. External Relations of Chibchan. Paper presented at the Intermediate Area Workshop I, the Chibchan and Arawakan Families: Linguistic and Cultural Traits, Lyon DDL, Université Lumière Lyon 2, April 2016.

Pache, Matthias. 2018. Contributions to Chibchan Historical Linguistics. Ph.D. dissertation, Universiteit Leiden.

Palancar, Enrique L. 2002. The origins of Agent markers. Berlin: Akademie Verlag. 
Payne, Doris L. \& Immanuel Barshi. 1999. ExternalPossession. Amsterdam/Philadelphia: John Benjamins.

Quesada Pacheco, Miguel Angel. 2008. Gramática de la lengua guaymí (ngäbe). Munich: Lincom Europa.

Quesada, Juan Diego. 2000. A Grammar of Teribe. Munich: Lincom Europa.

Quesada, Juan Diego. 2012. Gramática del buglere. Quito: Abya-Yala.

Stassen, Leon. 2009. Predicative Possession. Oxford: Oxford University Press.

Trask, Robert Lawrence. 1979. On the Origins of Ergativity. Ergativity: Towards a Theory of Grammatical Relations, ed. by Frans Plank, 385-404. London: Academic Press.

Traugott, Elizabeth Closs \& Bernd Heine. 1991. Approaches to Grammaticalization. Amsterdam/Philadelphia: John Benjamins.

Trillos Amaya, María, Gerardo Reichel-Dolmatoff \& Carolina Ortíz Ricaurte. 1989. Sierra Nevada de Santa Marta. Vols. 1-2. Bogotá: Colciencias.

Uhle, Max. 189o. Verwandtschaften und Wanderungen der Tschibtscha. Congreso Internacional de Americanistas session VII, Berlin, 1-6 October, 189o, 466-489. Berlin: Librairie W. H. Kühl.

Young, Philip D. \& Talmy Givón. 199o. The Puzzle of Ngóbére Auxiliaries: Grammatical Reconstruction in Chibchan and Misumalpan. Studies in Typology and Diachrony: Papers Presented to Joseph H. Greenberg on his 75th Birthday, ed. by Joseph H. Greenberg, William Croft, Keith M. Denning \& Suzanne Kemmer, 209-243. Amsterdam/Philadelphia:John Benjamins. 